Biogeosciences, 10, 3221-3239, 2013

www.biogeosciences.net/10/3221/2013/

doi:10.5194/bg-10-3221-2013

(C) Author(s) 2013. CC Attribution 3.0 License.

\title{
Sediment transport along the Cap de Creus Canyon flank during a mild, wet winter
}

\author{
J. Martín ${ }^{1}$, X. Durrieu de Madron ${ }^{2}$, P. Puig ${ }^{1}$, F. Bourrin ${ }^{2}$, A. Palanques ${ }^{1}$, L. Houpert ${ }^{2}$, M. Higueras ${ }^{2}$, \\ A. Sanchez-Vidal ${ }^{3}$, A. M. Calafat ${ }^{3}$, M. Canals ${ }^{3}$, S. Heussner ${ }^{2}$, N. Delsaut ${ }^{2}$, and C. Sotin ${ }^{2}$ \\ ${ }^{1}$ Institut de Ciències del Mar (CSIC), Passeig Marítim de la Barceloneta 37-49, 08003 Barcelona, Spain \\ ${ }^{2}$ CEFREM, CNRS-Université de Perpignan, Via Domitia, 52 avenue Paul Alduy, 66860 Perpignan, France \\ ${ }^{3}$ GRC Geociències Marines, Departament d'Estratigrafia, Paleontologia i Geociències Marines, Facultat de Geologia, \\ Universitat de Barcelona, Campus de Pedralbes, Martí i Franquès s/n, 08028 Barcelona, Spain
}

Correspondence to: J. Martín (jmartin@icm.csic.es)

Received: 28 November 2012 - Published in Biogeosciences Discuss.: 14 December 2012

Revised: 2 April 2013 - Accepted: 19 April 2013 - Published: 14 May 2013

Abstract. Cap de Creus Canyon (CCC) is known as a preferential conduit for particulate matter leaving the Gulf of Lion continental shelf towards the slope and the basin, particularly in winter when storms and dense shelf water cascading coalesce to enhance the seaward export of shelf waters. During the CASCADE (CAscading, Storm, Convection, Advection and Downwelling Events) cruise in March 2011, deployments of recording instruments within the canyon and vertical profiling of the water column properties were conducted to study with high spatial-temporal resolution the impact of such processes on particulate matter fluxes. In the context of the mild and wet 2010-2011 winter, no remarkable dense shelf water formation was observed. On the other hand, the experimental setup allowed for the study of the impact of E-SE storms on the hydrographical structure and the particulate matter fluxes in the CCC. The most remarkable feature in terms of sediment transport was a period of dominant E-SE winds from 12 to 16 March, including two moderate storms (maximum significant wave heights $=4$. 1 $4.6 \mathrm{~m}$ ). During this period, a plume of freshened, relatively cold and turbid water flowed at high speeds along the southern flank of the CCC in an approximate depth range of 150 $350 \mathrm{~m}$. The density of this water mass was lighter than the ambient water in the canyon, indicating that it did not cascade off-shelf and that it merely downwelled into the canyon forced by the strong cyclonic circulation induced over the shelf during the storms and by the subsequent accumulation of seawater along the coast. Suspended sediment load in this turbid intrusion recorded along the southern canyon flank oscillated between 10 and $50 \mathrm{mg} \mathrm{L}^{-1}$, and maximum currents speeds reached values up to $90 \mathrm{~cm} \mathrm{~s}^{-1}$. A rough estimation of $10^{5}$ tons of sediment was transported through the canyon along its southern wall during a 3-day-long period of storm-induced downwelling. Following the veering of the wind direction (from SE to NW) on 16 March, downwelling ceased, currents inside the canyon reversed from down- to up-canyon, and the turbid shelf plume was evacuated from the canyon, most probably flowing along the southern canyon flank and being entrained by the general SW circulation after leaving the canyon confinement. This study highlights that remarkable sediment transport occurs in the CCC, and particularly along its southern flank, even during mild and wet winters, in absence of cascading and under limited external forcing. The sediment transport associated with eastern storms like the ones described in this paper tends to enter the canyon by its downstream flank, partially affecting the canyon head region. Sediment transport during these events is not constrained near the seafloor but distributed in a depth range of 200-300 $\mathrm{m}$ above the bottom. Our paper broadens the understanding of the complex set of atmosphere-driven sediment transport processes acting in this highly dynamic area of the northwestern Mediterranean Sea.

\section{Introduction}

Continental margins are transitional areas between the land masses and the open sea where inputs of particulate matter 
from the former tend to accumulate due to gravitational settling of river plumes and the physical barrier imposed by along-shore currents and density fronts. Under certain conditions, sediments previously stored on the coast and the continental shelf can be remobilized and transported to greater depths. This transfer of organic and inorganic matter from shallow depths to the continental slope and basins strongly influences biogeochemical cycles, the structure and functioning of benthic ecosystems and the fate of pollutants delivered from coastal point sources (Jahnke et al., 1990; Pfannkuche, 1993; Puig et al., 1999).

Some processes that contribute to facilitate the acrossisobath exchange of water masses and entrained particulate matter are instabilities and meandering of slope currents (Flexas et al., 2002), wind-induced downwelling and upwelling, and the development of buoyancy-driven currents flowing downslope (Huthnance, 1995). Also, the presence of submarine canyons intersecting continental shelves can enhance across-shelf sediment transport, by intercepting the along-shore sediment drift, promoting and intensifying ageostrophic flows, focusing internal waves and tides or channelling density currents (Hickey, 1997; Puig et al., 2004; Martín et al., 2007, 2011; Allen and Durrieu de Madron, 2009; Palanques et al., 2011).

During the last decades, the Gulf of Lion (GoL) in the northwestern Mediterranean has been targeted by numerous observational programs covering different aspects of its present-day particle flux dynamics (Monaco et al., 1990; Heussner et al., 1996, 2006; Durrieu de Madron et al., 2008). Its wide continental shelf indented by numerous submarine canyons, the significant freshwater inputs feeding the shelf with terrestrial sediments, and an energetic oceanographic and meteorological regime combined with very weak tidal motions has made the GoL a natural laboratory to study landto-basin sediment transport processes driven mainly by seaatmosphere interactions.

The Cap de Creus Canyon (CCC) at the western end of the GoL is widely recognized as the main route for particulate matter transfer from the GoL coast and continental shelf to the slope and basin (Canals et al., 2006; Palanques et al., 2006, DeGeest et al., 2008). Most of the published literature on the off-shelf delivery of sediments through the CCC has focused on the impact of extreme events such as major floods and storms (Guillén et al., 2006; Bourrin et al., 2008), deep cascading (Canals et al., 2006, Puig et al., 2008, Pasqual et al., 2010; Palanques et al., 2012) or the combination of them (Palanques et al., 2006; Ulses et al., 2008a; Ribó et al., 2011).

The CASCADE (CAscading, Storm, Convection, Advection and Downwelling Events) cruise (1-23 March 2011) was designed to study with high resolution the main processes of water and mass transport operating from the shelf to the basin in the GoL region. A main task of the experimental design was to quantify the fluxes of organic and inorganic matter associated with open sea convection, dense shelf water cascading and storms impinging on the continental shelf.
This work makes use of hydrographical, hydrodynamic and particle flux data collected during the CASCADE cruise to study with unprecedented spatial and temporal resolution the effects of eastern storms in shelf-slope exchanges of water and particulate matter through the Cap de Creus submarine canyon. The present work aims to gain insight on the response of the canyon to meteorological conditions representative of an average year without extreme events.

\section{Study area}

The GoL is a micro-tidal, river-dominated continental margin stretching along a substantial part of the French Mediterranean. The continental shelf is wide and indented by submarine canyons mainly on its distal part. River discharge in the GoL is largely dominated by the Rhône River, the largest freshwater source opening to the western Mediterranean and likewise the main sediment source feeding the GoL. Additionally, numerous smaller rivers can yield significant inputs of freshwater and particulate matter in the form of flash floods (Bourrin et al., 2006). Most of the sediments delivered by GoL rivers are temporarily stored off their mouths (Drexler and Nittrouer, 2008) and afterwards remobilized and redistributed along the shelf by the action of storms and along-shore currents (Guillén et al., 2006).

The GoL is subject to an energetic meteorological regime, mainly during winter (Millot, 1990). On one hand, north (Mistral) and northwest (Tramontane) cold and dry winds induce loss of buoyancy of surface shelf waters through cooling and evaporation, eventually leading to the downslope sinking of surface waters until they reach their compensation depth, sometimes involving overspill from the shelf towards the slope in a phenomenon known as dense shelf water cascading (DSWC) (Bougis and Ruivo, 1954; Durrieu de Madron et al., 2005). On the other hand, E and SE (Marin) winds produce larger swells and significant erosion on the shelf (Guillén et al., 2006). The interplay of DSWC and shelf storms has been recognized as the main mechanism fuelling the offshore redistribution of particulate matter from the GoL (Durrieu de Madron et al., 2008; Palanques et al., 2008).

The across-margin export of total and organic matter in the GoL takes place preferentially through a network of submarine canyons (Buscail and Germain, 1997), which is one of the densest of the World Ocean (Harris and Whiteway, 2011). Nonetheless, the capacity to foster off-shelf sediment transport is not evenly distributed among GoL canyons, but tends to increase from east to west (Monaco et al., 1990; Heussner et al., 1996, 2006; Palanques et al., 2006). This longitudinal gradient is a result of the morphology of the margin (the distance from canyon heads to the coast decreases westward) and also of the hydrodynamic regime over the GoL, which is primarily governed by an along-slope current flowing cyclonically as part of the Northern Current, a larger oceanographic feature that extends from the Gulf of Genoa to the Gulf of Valencia (Millot, 1999). Coupled to the 
along-slope current, a density front is established between freshened shelf waters and denser open-sea water, which further reinforces the along-shore confinement of shelf waters and river plumes. The general westwards circulation promotes a convergence of water and entrained particles at the southwestern end of the GoL, a trend that is greatly enhanced under ESE winds, which intensify the cyclonic circulation on the GoL shelf and produce a sea level rise next to the coast, altogether promoting downwelling conditions (Ulses et al., 2008b; Palanques et al., 2008). Suspended sediments are also effectively pulled towards the southwestern end of the gulf during these events, owing to the entrainment of river plumes and mainly to the resuspension and advection of previously settled particles, given that erosion of shelf sediments is maximal under E-SE storms (Ferré et al., 2005; Guillén et al., 2006).

At the very end of the western GoL, the continental shelf narrows rapidly and the Cap de Creus peninsula (Fig. 1) imposes a barrier to the flow, exacerbating the concentration of water and entrained particles. Next to this geomorphologic bottleneck lies the CCC, deeply carved across the continental slope and thus offering a preferential route for water flowing along the shelf at depths below the canyon rim. Previous studies have ascertained that the CCC constitutes the main route for particulate matter dispersal from the GoL to the slope and basin, in particular during intense meteorological events when sediment fluxes can be up to two orders of magnitude higher in the CCC than in any other GoL canyon (Canals et al., 2006; Palanques et al., 2006, 2012).

Shelf-to-basin transport is maximal during winters of intense DSWC, as was the case during 1998-1999, 2004-2005 and 2005-2006 (Heussner et al., 2006; Canals et al., 2006; Puig et al., 2008; Palanques et al., 2012). Together with the off-shelf transport of dissolved and particulate matter entrained in the sinking dense water masses, the high water currents during these episodes have the potential to erode and shape the deep canyon floor (Canals et al., 2006; Puig et al., 2008).

The hydrological structure of the water column in the GoL is very variable, with the presence of various water masses that result from a wide range of mixing between exogenous water types, water masses formed locally or in adjacent areas, and freshwater inputs. The external water types are the Atlantic Water (AW) and the Levantine Intermediate Water (LIW). The AW fills the upper $\sim 250 \mathrm{~m}$ of the western Mediterranean and has its origin in the inflow of Atlantic waters at the Gibraltar Strait. After being severely modified during its long transit towards the study area, the characteristics of the so-called "old" Atlantic Water (oAW) at the GoL are $\theta>13^{\circ} \mathrm{C}$ and $S=38.0-38.2$ (Puig et al., 2013). The salty and warm LIW originates in the eastern Mediterranean and enters the western basin through the Strait of Sicily as an intermediate water mass infilling approximately the $250-800 \mathrm{~m}$ depth stratum of the NW Mediterranean water column. The hydrological characteristics of the LIW at the study area are variable depending on its age and hence its degree of mixing with other water masses but nonetheless display a clear salinity maximum $(S>38.45)$ and relative temperature maximum $\left(\theta>13^{\circ} \mathrm{C}\right)$ in hydrological profiles. During winter, strong, cold and dry northerlies promote the formation of dense shelf waters over the GoL $\left(\theta<13^{\circ} \mathrm{C} ; S<38.4\right)$ (Dufau-Julliand et al., 2004; Durrieu de Madron et al., 2005). Depending on the strength of winter cooling and evaporation and also on the degree of stratification of the water column, dense shelf waters can reach the basin and thus contribute to modifying the deep Northwestern Mediterranean Water, or they can detach at intermediate depths according to their buoyancy compensation level. In the last case, Western Intermediate Waters (WIW) are formed, with characteristics $\theta=12.6-13.0^{\circ} \mathrm{C}$; $S=38.10-38.30$ (Lapouyade and Durrieu de Madron, 2001).

\section{Materials and methods}

\subsection{Meteorological, wave and river discharge data}

Water discharge of rivers opening to the Gulf of Lion was measured by gauging stations located near river mouths and provided by the Compagnie Nationale du Rhône and the Banque HYDRO (French Ministry of Environment). We will hereafter consider on one hand the Rhône river discharge and, on the other, the total water discharge of coastal rivers opening to the central and western Gulf of Lion, taken as the sum of the contributions from the rivers Tech, Têt, Agly, Aude, Hérault, Orb, Lez and Vidourle. Significant wave height, peak period and wave direction were obtained by means of an upward-looking $600 \mathrm{kHz}$ Teledyne RDI ADCP equipped with a wave gauge, deployed at $27 \mathrm{~m}$ depth as part of the POEM coastal monitoring site (see Fig. 1a for location). A meteorological buoy installed at the same site provided wind speed and direction.

\subsection{Instrumented mooring lines}

\subsubsection{Temporary lines}

Two instrumented mooring lines were deployed during the CASCADE cruise along the western flank of the CCC at $42^{\circ} 21.61^{\prime} \mathrm{N}, 3^{\circ} 20.42^{\prime} \mathrm{E}(\mathrm{SF} 1$, water depth $=290 \mathrm{~m})$ and $42^{\circ} 20.31^{\prime} \mathrm{N}, 3^{\circ} 23.23^{\prime} \mathrm{E}$ (SF2, water depth $\left.=365 \mathrm{~m}\right)$, respectively (Fig. 1b). The mooring lines were deployed on 3 March and recovered on 21 March 2011.

Both lines were equipped with a similar array of instruments, comprising a downward-looking $300 \mathrm{kHz}$ Teledyne RDI acoustic Doppler current profiler (ADCP) at $160 \mathrm{~m}$ above the bottom (mab); three Seapoint turbidimeters (AQUA logger 520 from Aquatec Group) at 10, 75 and 115 mab, respectively; a Technicap PPS3/3 sediment trap at $40 \mathrm{mab}$; and a Seabird SBE 37-SMP probe at 8 mab. ADCPs profiled $110 \mathrm{~m}$ of water column (from 40 to $150 \mathrm{mab}$ ) in $2 \mathrm{~m}$-wide cells at a sampling rate of $5 \mathrm{~min}$. The SBE37SMP 


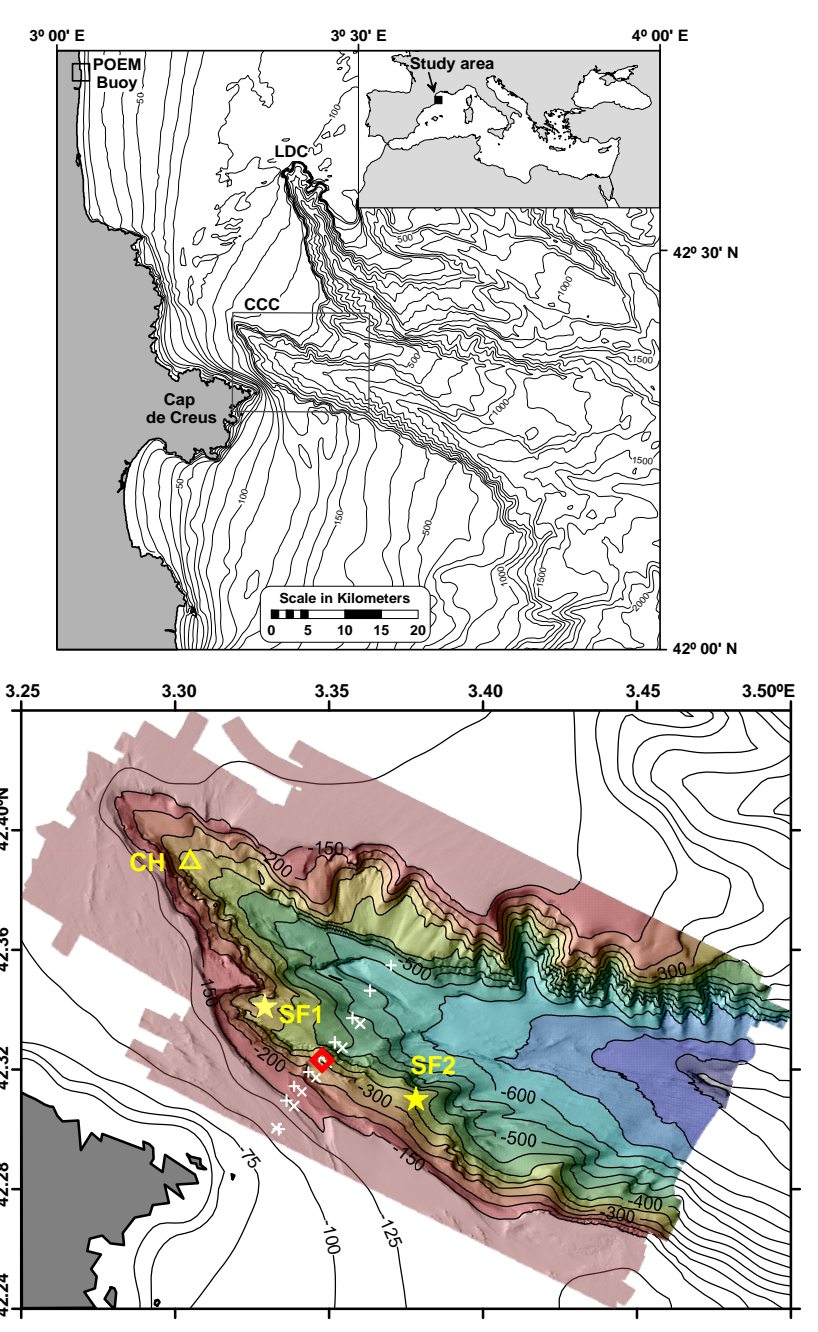

Fig. 1. (a) Bathymetric chart of the western Gulf of Lion showing the main submarine canyons in this area, the Lacaze-Duthiers (LDC) and Cap de Creus Canyon (CCC). The position of the POEM coastal site is also shown; (b) multibeam bathymetry of the CCC provided by Fugro Survey Ltd. and AOA Geophysics Inc. Stars mark the location of two temporary instrumented lines (SF1 and SF2) maintained in the southern canyon flank from 3 to 21 March 2011. The triangle marks the location of a long-term mooring line in the canyon head $(\mathrm{CH})$. The position of a high-resolution CTD station "CX" (11-14 March) is marked with a red diamond. White crosses represent CTD casts' positions during two cross-canyon hydrological transects conducted on 14 and 21 March, the longest one corresponding to 14 March.

probe measured temperature, conductivity and pressure every $3 \mathrm{~min}$. Depth, potential temperature, practical salinity and potential density anomaly were calculated based on the equation of state of seawater EOS-80 (Fofonoff and Millard, 1983). The SBE 37 SMP sensors were calibrated using a pre-cruise calibration, yielding an initial accuracy of $0.002{ }^{\circ} \mathrm{C}$ on temperature and 0.005 on salinity. The standard deviation on ADCP current speed and direction measure- ments was $1.3 \mathrm{~cm} \mathrm{~s}^{-1}$ and $2^{\circ}$, respectively. All raw time series were checked to remove spurious data points. Seapoint turbidimeters were programmed to measure water turbidity in Formazin Turbidity Units (FTU) every $20 \mathrm{~s}$ in auto-gain mode. FTU values were transformed into suspended sediment concentration ( $\mathrm{SSC}, \mathrm{mg} \mathrm{l}^{-1}$ ) using the calibration by Guillén et al. (2000).

Sediment traps were programmed to sample the downward particle flux at $35 \mathrm{~h}$ intervals. In order to avoid grazing by zooplankton and the remineralization of organic compounds, the cups were poisoned with $2 \%$ formaldehyde in filtered seawater prior to deployment. The procedures used to treat sediment trap samples and to obtain the downward fluxes $\left(\mathrm{g} \mathrm{m}^{-2} \mathrm{~d}^{-1}\right)$ are described in Heussner et al. (1990). Grainsize analysis of trap samples was performed on a Coulter LS 230 laser particle size analyser, after pre-treatment of the dry sample with $10 \% \mathrm{H}_{2} \mathrm{O}_{2}$ and sodium polyphosphate solution to remove organic matter and disaggregate the sample.

\subsubsection{Long-term mooring line at the canyon head}

In addition to the two high-resolution, short-lived mooring deployments, another mooring line was present at the CCC head $\left(42^{\circ} 23.15^{\prime} \mathrm{N}, 3^{\circ} 19.53^{\prime} \mathrm{E}\right.$; $300 \mathrm{~m}$ depth; Fig. 1b), as part of a long-term monitoring programme active since autumn 2004. This line was equipped with a near-bottom set of instruments comprising an Aanderaa RCM9 current meter ( $5 \mathrm{mab}$; sampling rate $30 \mathrm{~min}$ ), an AQUA logger 520 Seapoint turbidimeter ( $6 \mathrm{mab}$; sampling rate $2 \mathrm{~min}$ ) and a Technicap PPS3/3 sediment trap (25 mab; sampling interval 15 days). Data from this line will be used to weigh the relevance of water and particle fluxes along the southern canyon flank against those on the canyon head $(\mathrm{CH})$, and also as a reference to put the main study period (3-21 March 2011) into a broader perspective.

Current data were rotated when necessary to meet the main canyon axis direction $\left(\sim 130^{\circ}\right)$. Reported positive (negative) values are considered up-canyon (down-canyon). SSC obtained from turbidimeters and current speeds (ADCP cells at SF1 and SF2; single-point current meter at $\mathrm{CH}$ ) measured at similar depths were combined to obtain the suspended sediment flux (i.e. the horizontal transport of particles in suspension pulled by the water flow) in units of $\mathrm{mg} \mathrm{m}^{-2} \mathrm{~s}^{-1}$. This approach could be applied only to the depth levels where simultaneous turbidity and current measurements were available (75 and 115 mab at lines SF1 and SF2 and 5 mab at line $\mathrm{CH})$.

\subsubsection{Assessment of mooring line dynamics}

The dynamics of the mooring lines were assessed using the Mooring Design and Dynamics (MDD) software (Dewey, 1999) and validated by comparing the modelled deepening of the line to the pressure sensor located in the ADCP units. The simulation of the behaviour of the ADCP at 160 mab 
and the sediment trap at 40 mab for different observed speeds compared well with the observed deepening of the line (Fig. 2). Deepening and tilting increased markedly under current speeds surpassing $40 \mathrm{~cm} \mathrm{~s}^{-1}$ (an approximate $30 \%$ of current records were above that threshold at both lines). According to the MDD simulations, during the maximum current speeds $\left(90 \mathrm{~cm} \mathrm{~s}^{-1}\right)$ recorded at $\mathrm{SF} 2$, the sediment trap originally at $40 \mathrm{mab}$ deepened to only a few metres above the seafloor and its inclination was nearly horizontal. Such high velocities were rarely reached. At line SF2 currents were higher than $80 \mathrm{~cm} \mathrm{~s}^{-1}$ only $0.4 \%$ of the time, while at SF1 the highest speed range $\left(70-80 \mathrm{~cm} \mathrm{~s}^{-1}\right)$ was reached $0.3 \%$ of the recording time. These results raise concerns particularly over the validity of sediment-trap-derived particle fluxes during high current speed periods, which will be considered hereafter as qualitative data. On the other hand, the remarkable homogeneity of currents estimated at the two critical (due to the concomitant presence of turbidimeters at the same points) ADCP bins during the episodes of maximum current speed indicates that ADCP deepening has not severely affected the reliability of these ADCP cells and that they can be ascribed to its nominal depths (75 and $115 \mathrm{mab}$ ) in spite of the transitory depth changes.

\subsection{Hydrological vertical profiling and ship-based ADCP data}

Vertical profiling of water column properties was conducted intensively during the CASCADE cruise, covering a wide set of coastal, shelf, slope and open-sea stations. The conductivity-temperature-depth (CTD) profiles used in this work are restricted to the CCC area and comprise a highresolution temporal sampling at a single station between the two temporary mooring lines during the period of the storm, and two cross-canyon transects after the storm (see Fig. $1 \mathrm{~b}$ for station locations). CTD casts were carried out using a Seabird 911Plus CTD probe equipped with a SBE 32 Carousel water sampler. Thirteen data channels (pressure, dual temperature and conductivity with pump, dissolved oxygen, light attenuation, turbidity, fluorescence, dissolved oxygen, photosynthetically active radiation, surface photosynthetically active radiation, colored dissolved organic matter, and altimetry) were measured at a rate of $24 \mathrm{~Hz}$. Temperature and salinity were corrected using pre- and post-cruise calibrations, yielding a precision of $0.01^{\circ} \mathrm{C}$ on temperature and 0.003 on salinity. The casts were conducted from the surface to a few metres above the seafloor whenever possible. A low-pass filter was used to compensate for the different time response of the sensors and to remove outliers. A ship-roll and minimum probe velocity filter $\left(<0.10 \mathrm{~m} \mathrm{~s}^{-1}\right)$ was applied to each cast to disallow pressure slowdowns and reversals. After filtering, the downcast portion of each cast was pressure-averaged and sequenced into $1 \mathrm{db}$ pressure intervals. The $1 \mathrm{db}$-averaged pressure, temperature and conductivity data were used to compute depth, potential temperature,
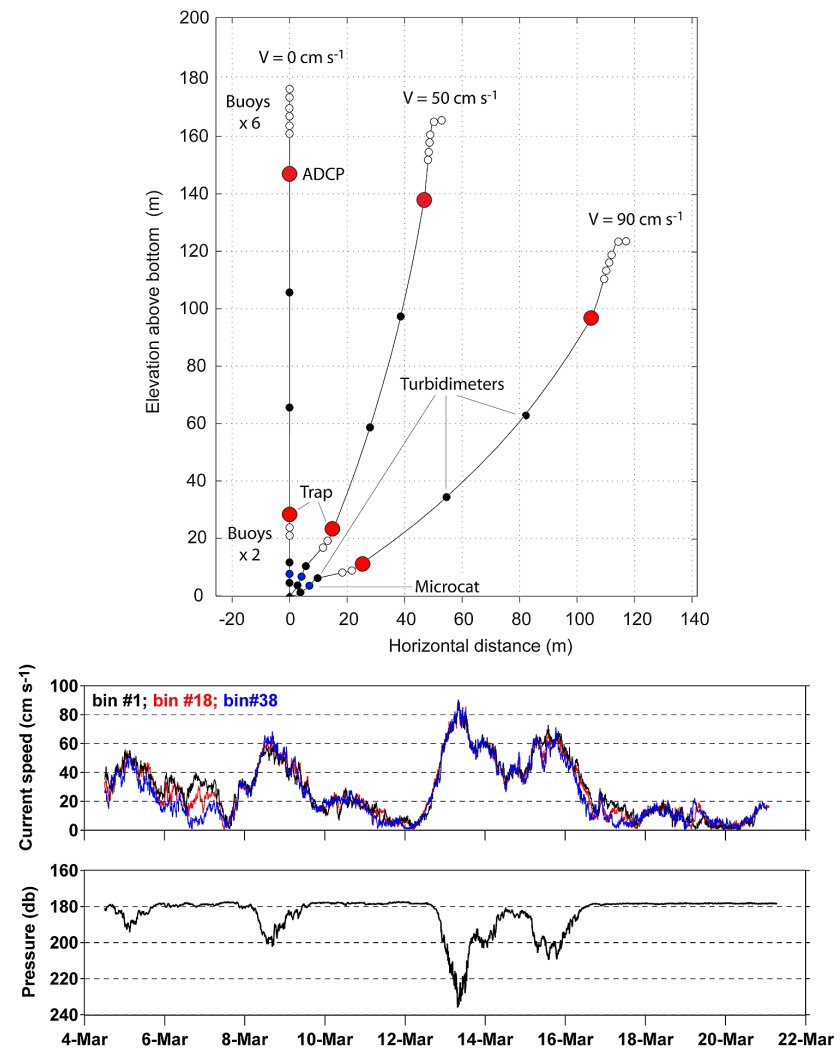

Fig. 2. Top: mooring dynamics as calculated by the Mooring Design and Dynamics software under three selected current speeds; bottom: pressure and current speeds measured by an ADCP attached $160 \mathrm{~m}$ above the bottom to the temporary mooring line (SF2) that experienced the strongest currents. Current speeds correspond to three selected ADCP bins: the topmost bin and the two more critical bins corresponding to the position of Seapoint turbidimeters attached to the lines.

salinity and potential density anomaly. Temperature is ITS90 and salinity is PSS-78. Density was calculated based on the equation of state of seawater EOS80 (Fofonoff and Millard, 1983). Water turbidity, measured in FTUs by a Seapoint sensor, was transformed into suspended sediment concentration (SSC) following the calibration by Guillén et al. (2000). Current speed data from a ship-based ADCP (RDI-Ocean Surveyor, $38 \mathrm{kHz}$ ) profiling 0-700 $\mathrm{m}$ in $16 \mathrm{~m}$-wide cells were also used. The ADCP data were processed with the Common Oceanographic Data Access System (CODAS) software (Firing et al., 1995), in agreement with the best practices suggested by the Go-Ship Group (Firing and Hummon, 2010). Bottom-track calibration was made to determine precisely transducer orientation relative to the heading sensor, and then the data were corrected for possible problems in the navigation recordings and bad ADCP bins/profiles. 


\section{Results}

\subsection{General setting for winter 2010-2011}

Time series of meteorological and wave data recorded by the POEM buoy at the Têt river mouth and water discharge of rivers opening to the Gulf of Lion during winter 2010-2011 are shown in Fig. 3. In order to understand the sediment fluxes observed during the CASCADE cruise in a broader context, near-bottom temperature, SSC and downward mass flux at the permanent monitoring station in the $\mathrm{CH}$ site (see location in Fig. 1b) during the entire winter 2010-2011 are also shown in Fig. 3.

As usual in the study area during wintertime (Ulses et al., $2008 \mathrm{~b}$, and references therein), the most frequent and in general stronger winds were NW (Tramontane), alternated by shorter periods of eastern and SE (Marin) winds. A period of sustained Tramontane with wind speeds up to $12 \mathrm{~m} \mathrm{~s}^{-1}$ preceded the beginning of the CASCADE cruise (1-23 March 2011). Eastern winds were more frequent during the cruise than in any other period of winter 2010-2011 and were particularly persistent and intense from 12 to 16 March. In total, three E-SE storms hit the GoL shelf during the study, peaking on 8,13 and 15 March with maximum significant wave heights (Hs) of 3.3, 4.6 and $4.1 \mathrm{~m}$ and maximum wave peak periods of 10.1, 10.2 and 9.4, respectively. These wave conditions correspond to typical winter storms in the region. According to their maximum $\mathrm{Hs}$, the return periods of the reported storms are between 1 and 2 yr (Guizien, 2009). The 13 March storm was the most remarkable of the three in terms of wave energy, particularly in the central GoL, its effects being comparatively milder in the western sector of the gulf (DREAL, 2011).

The sustained E and SE winds from 12 to 16 March pulled a Mediterranean humid air mass towards southern France, forcing precipitation by orographic control on the Massif Central and mainly the Pyrenees. In contrast, precipitations were abnormally weak in the rest of France including most of the Rhône watershed (http://www.eaufrance.fr/docs/bsh/ 2011/04/precipitations.php). As a consequence, the contribution of regional rivers to the total water discharge in the GoL was unusually high, accounting for up to $70 \%$, contrasting with a usual contribution of only $10-20 \%$ (the rest corresponding to the Rhône River alone). The highest river discharges of coastal rivers for the entire winter were measured on 16 March $\left(3950 \mathrm{~m}^{3} \mathrm{~s}^{-1}\right)$, when the dominant winds had already changed from $\mathrm{E}$ to NW direction and $\mathrm{Hs}$ was less than $2 \mathrm{~m}$ (Fig. 3).

Downward particle fluxes at $\mathrm{CH}$ were more important in December-January (10-30 $\mathrm{g} \mathrm{m}^{-2} \mathrm{~d}^{-1}$, Fig. 3) and lower than $10 \mathrm{~g} \mathrm{~m}^{-2} \mathrm{~d}^{-1}$ in February and March, suggesting preferential accumulation of sediment at the canyon head during early winter, when the Rhône river discharge was also higher. Several decreases of near-bottom temperature simultaneous to increases of current speed and SSC were observed at $\mathrm{CH}$, in general associated with E-SE storms or strong Tramontane wind gusts. These episodes of sediment transport were less important during the period of eastern storms and river flooding in March than early in the winter, particularly in December when water temperature decreases were strongest (Fig. 3).

\subsection{Currents and sediment fluxes at the canyon head during the CASCADE cruise}

Water temperature, current speed and particle flux data at the CH site from 1 to 23 March 2011 along with basic hydrometeorological parameters obtained during the same period are shown in detail in Fig. 4.

Following a 10-day-long period of NW winds just before the beginning of the cruise, near-bottom currents were directed down-canyon simultaneously to a decrease of nearbottom water temperature from 3 to 6 March. This trend reversed back by 7 March, when currents were weaker and up-canyon, and temperature was higher than $13^{\circ} \mathrm{C}$, suggesting the presence of LIW at $\sim 300 \mathrm{~m}$ at the canyon head. On 8 March, the first eastern storm (maximum $\mathrm{Hs}=3.3 \mathrm{~m}$ ) of the monitored period hit the western GoL. For the two days following this storm, currents (up to $45 \mathrm{~cm} \mathrm{~s}^{-1}$ ) were directed down-canyon and LIW withdrew from the canyon head. This storm did not cause a noticeable increase at the monitored station in terms of horizontal or downward mass fluxes. On the contrary, the two combined eastern storms of 13 and 15 March clearly impacted the canyon head area, in terms of high current speeds $\left(>60 \mathrm{~cm} \mathrm{~s}^{-1}\right.$ ) and SSC (up to $7 \mathrm{~g} \mathrm{~L}^{-1}$ ), resulting in suspended sediment fluxes between 3 and $4 \mathrm{~g} \mathrm{~m}^{-2} \mathrm{~s}^{-1}$ (Fig. 4). The sum of regional rivers' discharge peaked between 16 and 17 March, that is, after the main period of sediment transport. After 16 March, severe fouling of the turbidity sensor prevented the estimation of SSC. In any case, the transport associated with a hypothetical increase of SSC after 17 March would have not been significant taking into account the low current speeds from that date till the end of the cruise (Fig. 4). Cumulative sediment transport at $5 \mathrm{mab}$ at the canyon head was slightly lower than 0.6 ton $\mathrm{m}^{-2}$ for the entire study period.

\subsection{Sequence of hydrological changes in the water column during the 12-14 March stormy period}

On the night of 11 March, in coincidence with the approach of the strongest eastern storm of the 2010-2011 winter, R/V l'Atalante positioned on a fixed station (CX) in the CCC to monitor the effects of the storm on the hydrology and particle fluxes in the canyon with high temporal resolution. The location of CX was chosen in an intermediate position between the 2 temporary moored lines (nominal position: $42^{\circ} 20.70^{\prime} \mathrm{N} ; 3^{\circ} 21.64^{\prime} \mathrm{E}, 292 \mathrm{~m}$ depth; see Fig. 1b). Thirtytwo consecutive CTD casts were conducted at this station from 11 March at 21:45 to 14 March at 06:28 (UTC time). 


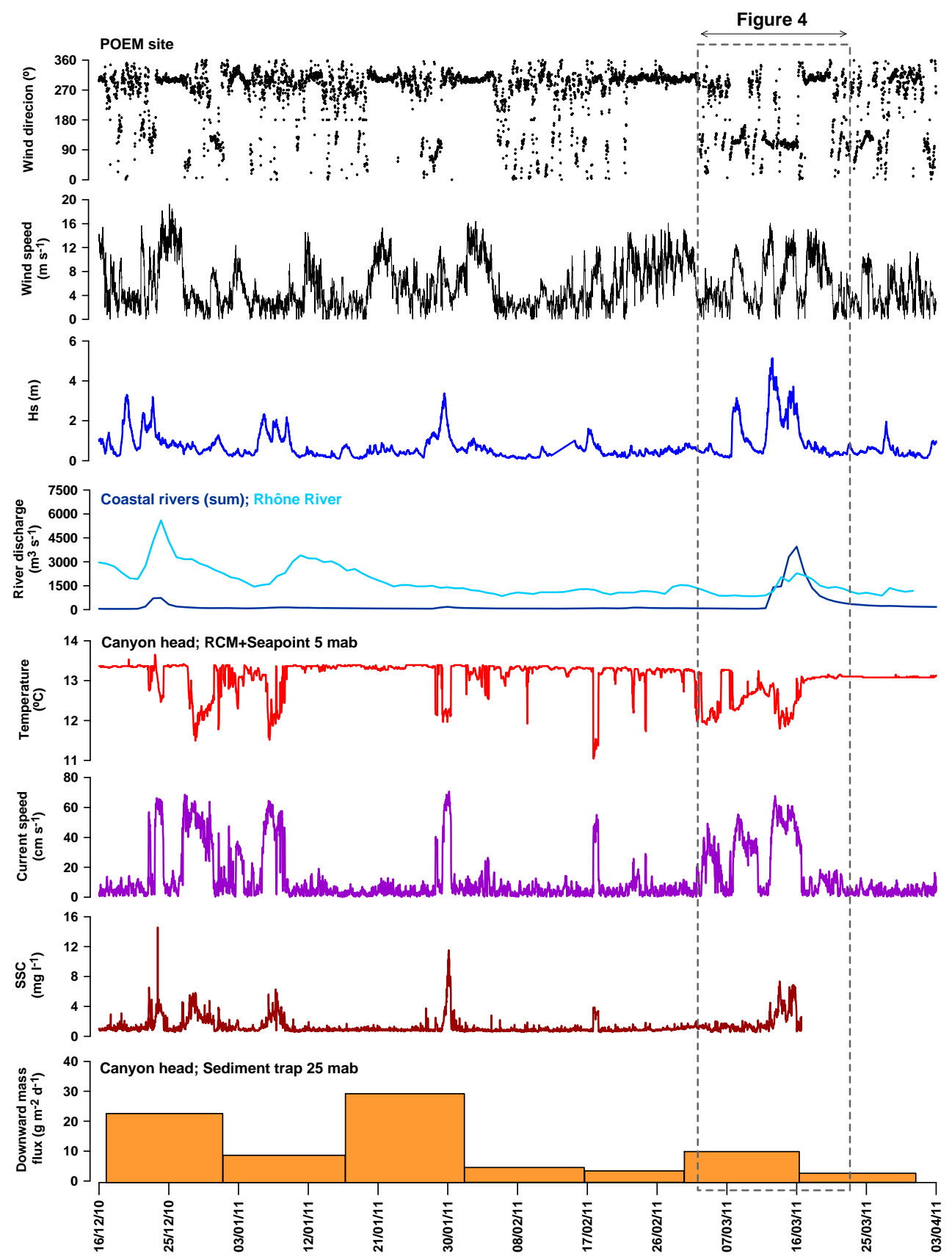

Fig. 3. General meteorological, hydrological and oceanographical setting in the study area, and hydrodynamic and particle flux response at the semi-permanent mooring line installed at the Cap de Creus Canyon head during winter 2010-2011. From top to bottom: wind speed, wind direction and significant wave height recorded at the POEM site (see Fig. 1a for location); mean daily water discharge of the Rhône River and the sum of coastal rivers opening to the Gulf of Lion; near-bottom water temperature, current speed, suspended sediment concentration and downward mass flux at the canyon head (300 $\mathrm{m}$ water depth). The dotted square marks the dates of the CASCADE cruise.

Contour plots of water temperature, salinity, density anomaly (sigma-theta) and turbidity during this period are plotted in Fig. 5. Water currents were also monitored by means of a ship-based ADCP. Current speed and direction at $210 \mathrm{~m}$ depth (the deepest ADCP cell that provided valid measurements) are also shown in Fig. 5.
During the first phase of monitoring at the CX station (11$12 \mathrm{March}$ ), warmer and less-dense water was progressively pushed down, eventually reaching the seafloor at $300 \mathrm{~m}$ depth. An increase of turbidity was also noticed near the bottom on 12 March, likely related to the forced displacement of the resident water, as also indicated by increasing current 


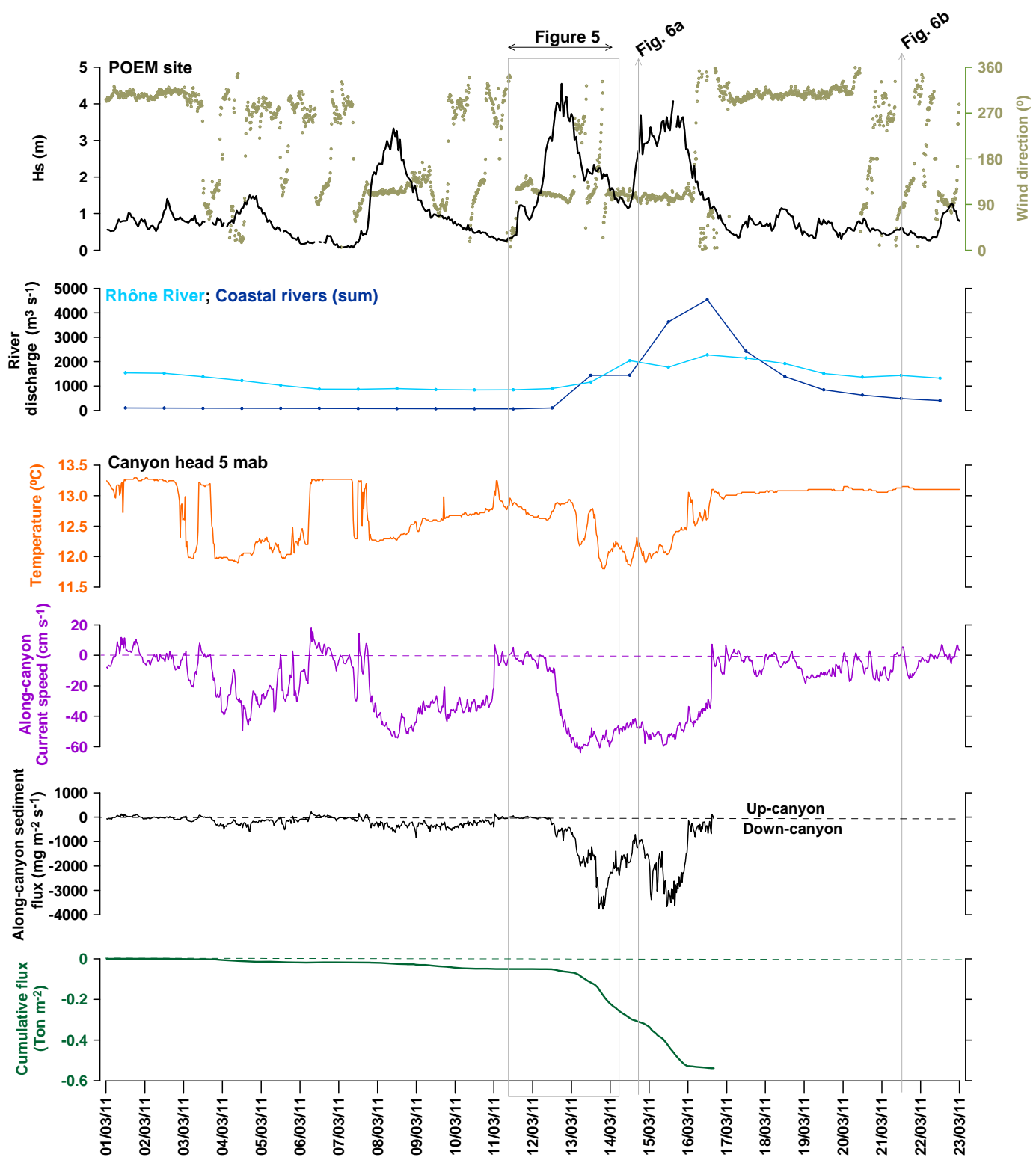

Fig. 4. Meteorological, hydrological and hydrodynamic context in the study area during the CASCADE cruise. From top to bottom: wind direction and significant wave height measured at the POEM coastal site; mean daily water discharge of the Rhône River and the sum of coastal rivers opening to the Gulf of Lion; near-bottom water temperature, along-canyon ( $130^{\circ}$ rotated) current speed, sediment flux and cumulative sediment transport (positive values are offshore; negative onshore) at the canyon head. The dotted square marks the dates of a 3-day fixed CTD station (see the text and Figs. 5, 6). Vertical dotted lines correspond to two across-canyon CTD transects conducted before and after the main stormy period.

speeds (Fig. 5). Worsening weather conditions on the night of 12-13 March caused an accident that forced the discontinuation of the CTD casts from 12 March at 23:06 to 13 March at 07:33. Once the CTD was fixed and vertical profiling resumed, the hydrological structure of the water column had drastically changed. A water mass characterized by relatively low salinity $(37.65-38.00)$, low temperature $\left(11.5-12.5^{\circ} \mathrm{C}\right)$, high dissolved oxygen concentration $\left(5.5-5.7 \mathrm{~mL} \mathrm{~L}^{-1}\right)$ and high suspended sediment load (3-8 $\left.\mathrm{mg} \mathrm{L}^{-1}\right)$ had occupied the deepest layer ( $\sim 200-300 \mathrm{~m}$ depth) of the canyon at the CX station. Currents at $210 \mathrm{~m}$ depth also changed notably between the two sampling phases here considered, from relatively weak and isotropic currents at the beginning of the measuring period to much stronger (up to $90 \mathrm{~cm} \mathrm{~s}^{-1}$ ), and clearly oriented along-canyon $\left(\sim 130^{\circ}\right)$ when the cold and turbid water body intruded the canyon.

Two across-canyon CTD transects were conducted after the monitoring at the CX station was completed. The first one 


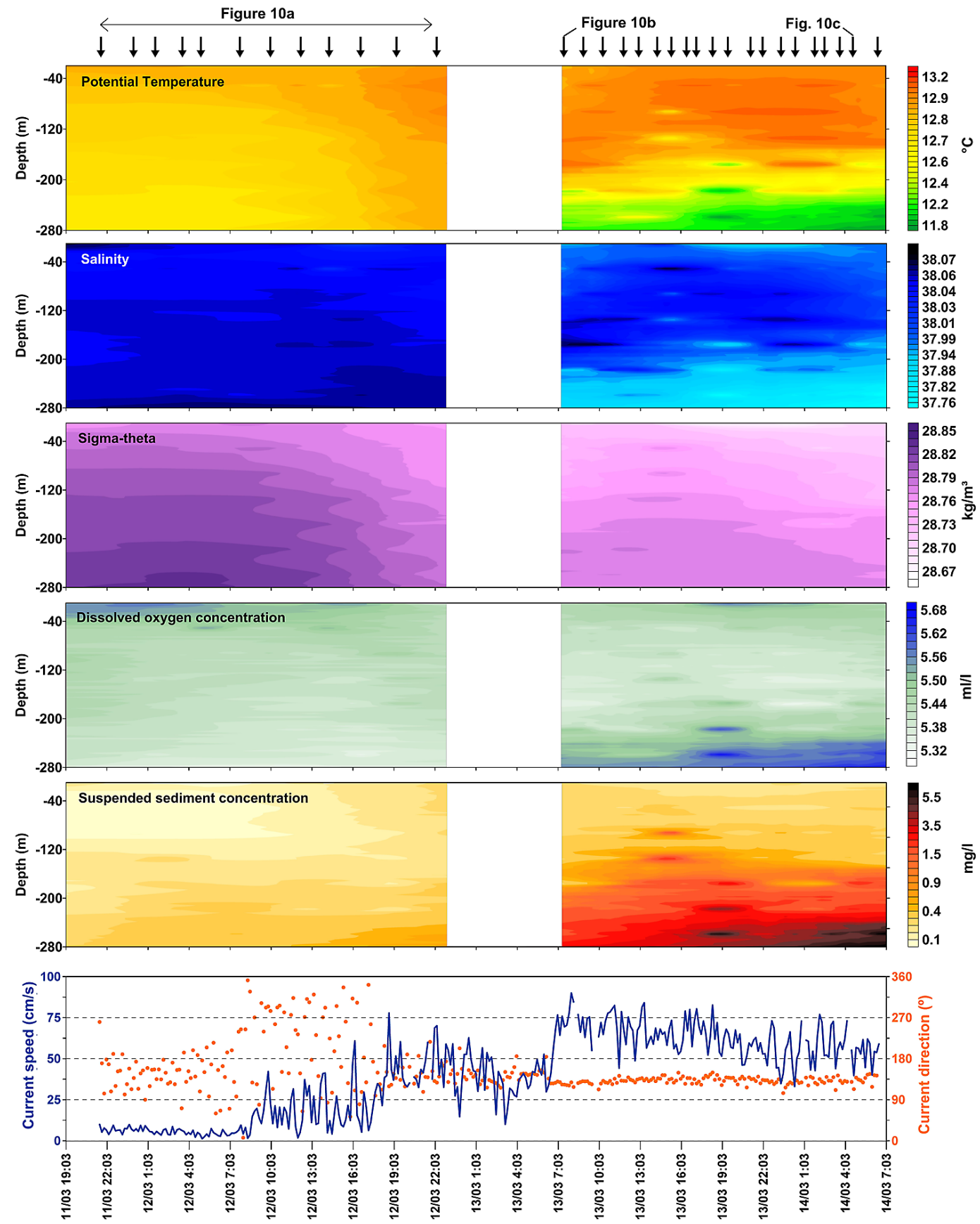

Fig. 5. Distribution of water column properties during the high-resolution temporal sampling at station CX in the Cap de Creus Canyon (see Fig. $1 \mathrm{~b}$ for location). From top to bottom: potential temperature, salinity, density, dissolved oxygen concentration, and suspended sediment concentration. Arrows indicate the temporal distribution of CTD casts used to create the interpolated contours. Current speed and direction at $210 \mathrm{~m}$ depth measured by an ADCP installed on the ship hull are also shown.

was conducted immediately on 14 March, still under conditions forced by the prevalent easterlies. The second one was conducted on 21 March after a period of northerlies. The across-canyon contours of salinity, temperature, density anomaly, dissolved oxygen concentration and suspended sediment concentration for each of these transects are shown in Fig. 6.

The 14 March transect (Fig. 6a) reveals the same bottom water mass observed at station CX, flowing along the southern canyon in an approximate depth range of $150-350 \mathrm{~m}$ and extending about $2 \mathrm{~km}$ from the flank into the canyon 
a. 14 March 2011
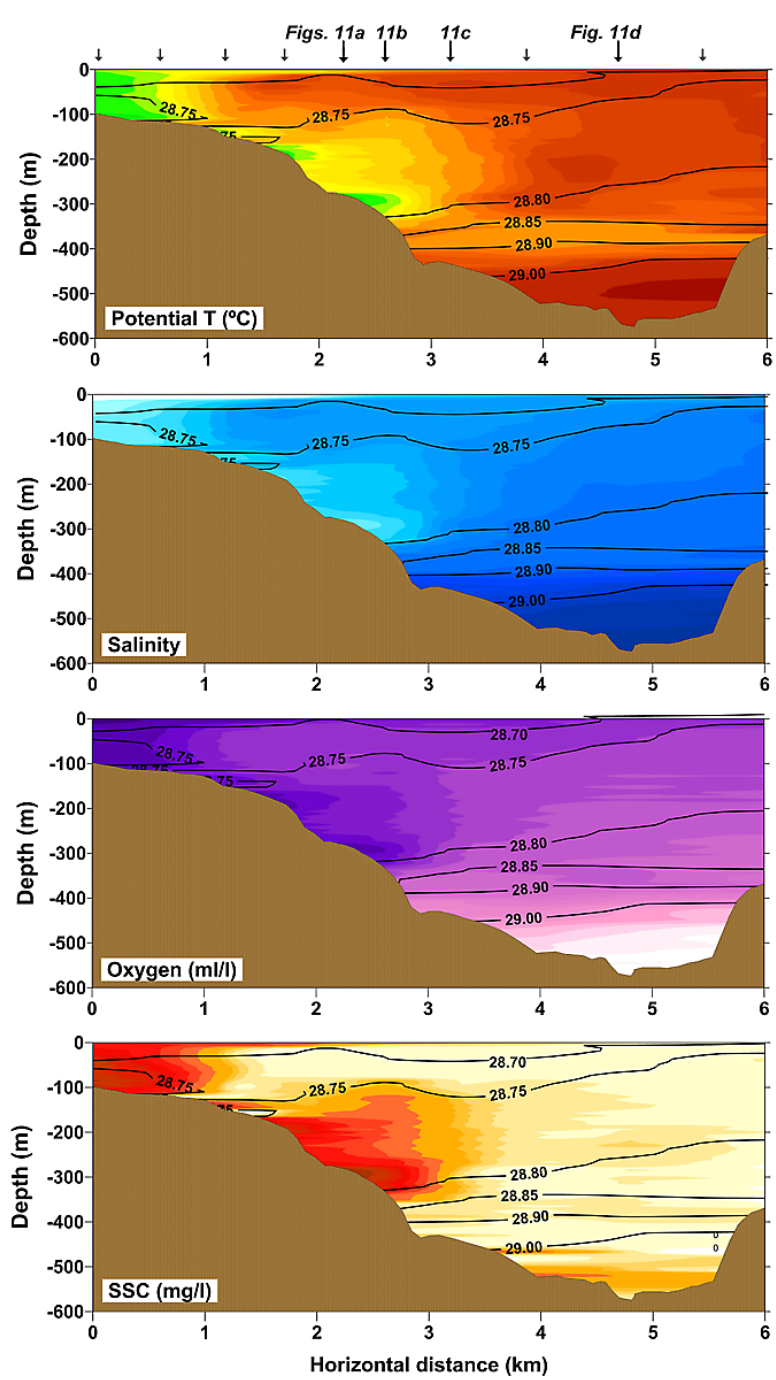

b. 21 March 2011
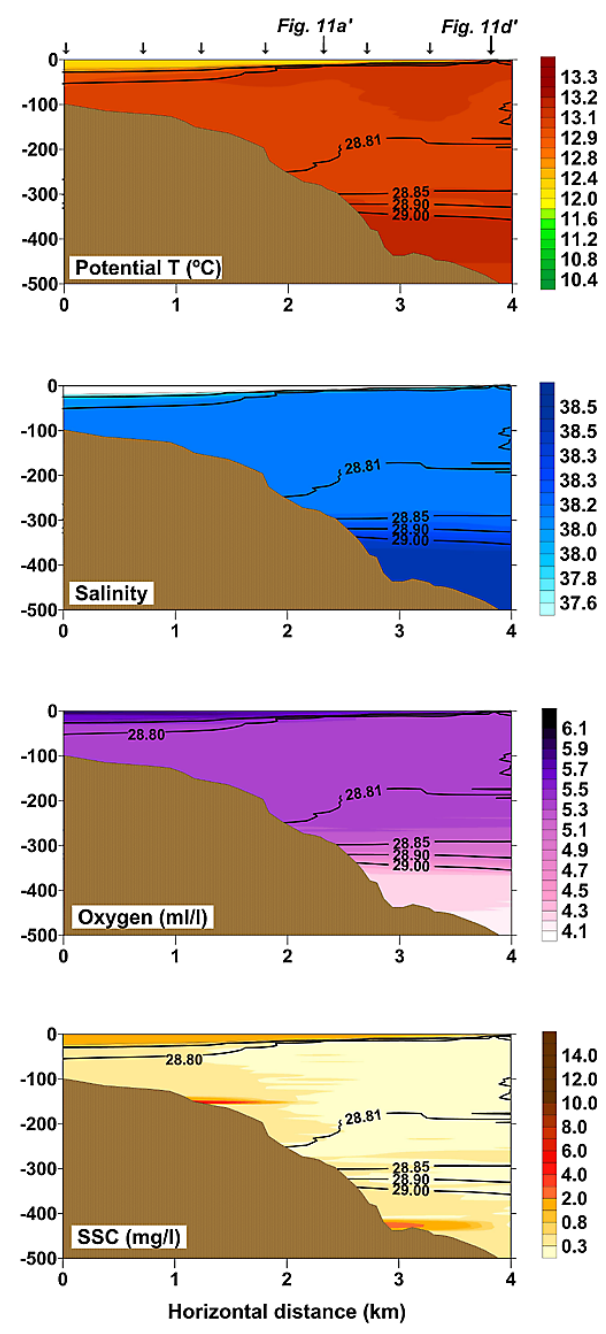

Fig. 6. Distribution of water column properties in the Cap de Creus Canyon during two across-canyon (= orthogonal to the canyon axis) CTD transects conducted on 14 and 21 March 2011 (left and right panels, respectively). From top to bottom: water salinity, potential temperature, dissolved oxygen concentration and suspended sediment concentration. Isolines of water density anomaly are overlaid on all these contours. Arrows on top mark the temporal distribution of CTD casts used to create the contours.

axis. SSC within the observed plume was in the range 2$14 \mathrm{~m} \mathrm{~L}^{-1}$. Underlying this freshened, cold and turbid water mass, a much less turbid water mass with hydrological characteristics possibly indicative of WIW could be detected. Further, deeper into the canyon axis, LIW was apparent at $\sim 500 \mathrm{~m}$ depth.

A second CTD transect following approximately the same trajectory as the first one was conducted a week later on 21 March (Fig. 6b), 4 days after the end of the easterlies period. The hydrological structure of the water column had changed dramatically with respect to 14 March, showing a substantial shoaling of the isopycnals. A remarkably homogenous water mass with the hydrological properties of oAW and low SSC filled the upper $400 \mathrm{~m}$ of the water column inside the canyon, replacing the turbid, cold and freshened intrusion as well as the underlying water mass with WIW characteristics noticeable on 14 March.

\subsection{Horizontal and downward mass fluxes in the south canyon flank}

Time series of temperature, current speed, SSC, and suspended and downward mass flux at the two lines deployed on the southern canyon flank (SF1, SF2), together with significant wave height and river discharge in the study area, are shown in Figs. 7 and 8, respectively. 

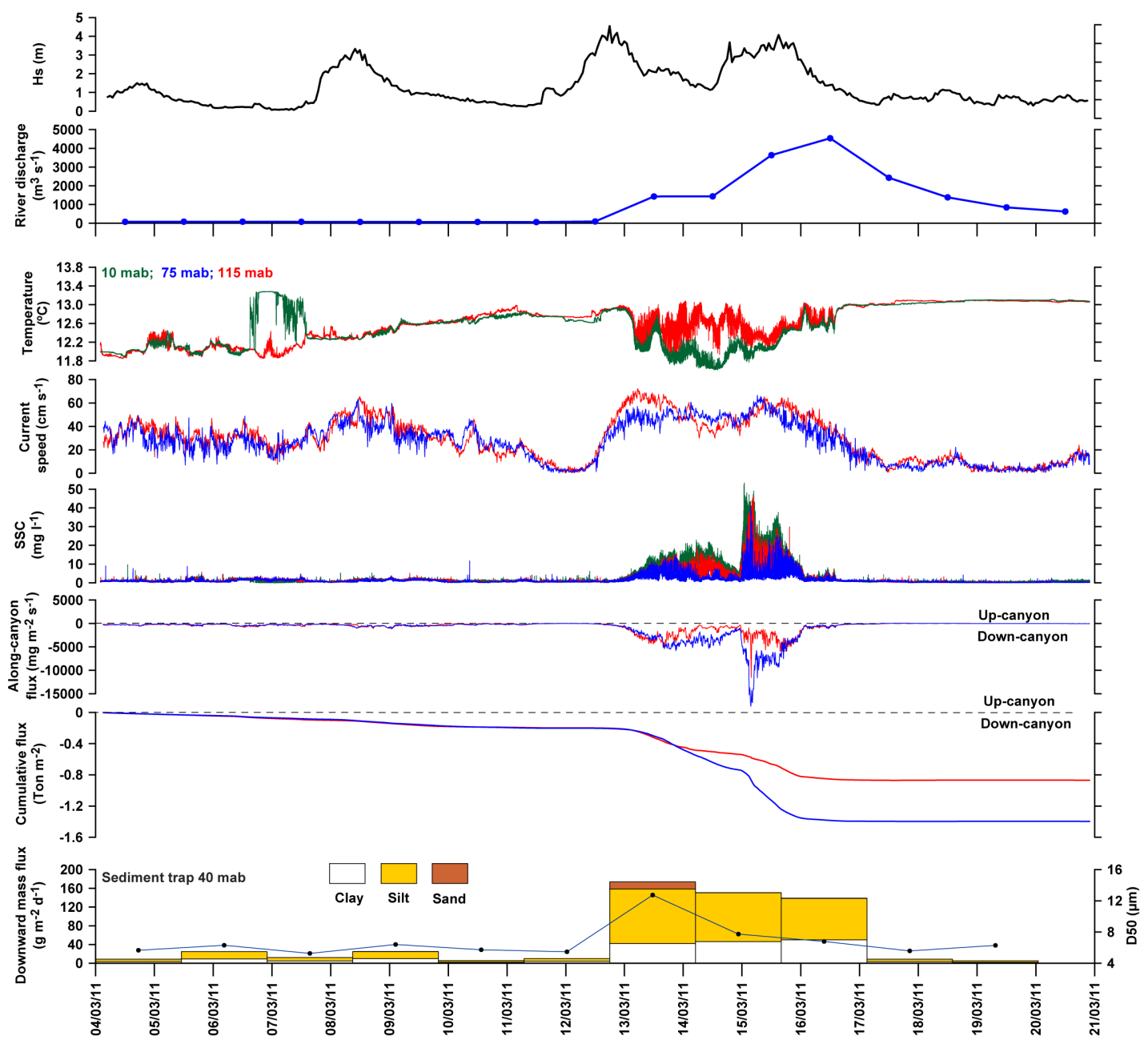

Fig. 7. Time series of water and sediment fluxes in the south flank of the Cap de Creus Canyon (mooring SF1, see Fig. 1b for location). From top to bottom: significant wave height measured at the POEM coastal site; total river discharge from coastal rivers opening to the Gulf of Lion (i.e. excluding the Rhône); in situ water temperature (measured by 3 Seapoint Aqualoggers), current speed measured by the ADCP at Seapoint depths, and suspended sediment concentration (Seapoint); along-canyon sediment flux (negative values down-canyon); cumulative transport calculated from the precedent flux; downward mass flux measured by a sediment trap. Trap fluxes are divided in three components according to the major grain-size classes; the median of the grain-size distribution (d50) in sediment trap samples is also shown.

\subsubsection{Line SF1}

At this line, SSC was lower than $4 \mathrm{mg} \mathrm{L}^{-1}$ until 13 March without any clear signal of the 8 March storm except for a timid increase of current speed that did not produce a significant sediment transport. During the two consecutive storms of 13-15 March, SSC increased to $10-50 \mathrm{mg} \mathrm{L}^{-1}$ while current speed reached up to $80 \mathrm{~cm} \mathrm{~s}^{-1}$, resulting in suspended sediment fluxes increasing by up to four orders of magnitude, up to $15 \mathrm{~g} \mathrm{~m}^{-2} \mathrm{~s}^{-1}$ measured at $75 \mathrm{mab}$ during the last storm (15n March). The cumulative sediment transport was almost 1.5 ton $\mathrm{m}^{-2}$ at $75 \mathrm{mab}$ and 0.85 ton m$^{-2}$ at $115 \mathrm{mab}$. The downward mass flux estimated from sediment traps increased to up to two orders of magnitude and was relatively stable around $125-150 \mathrm{~g} \mathrm{~m}^{-2} \mathrm{~d}^{-1}$ during the main stormy pe- riod. Silt dominated the grain-size distribution of particles collected by the trap during the entire deployment, but particles were coarsest, approaching sand size, during the period of highest horizontal and downward flux (Fig. 7).

\subsubsection{Line SF2}

In contrast to the canyon head line and SF1, the effects of the 8 March storm were noticeable at this station as an increase of both SSC and downward mass flux. However, as was the case at SF1, the main period of sediment transport was mainly concentrated in the stormy period of 13-15 March and preceded the flooding of regional rivers. Current speeds were even higher at this site, reaching up to $90 \mathrm{~cm} \mathrm{~s}^{-1}$ during the peak of the 13 March storm. The 
strongest sediment transport pulse took place during the last storm (15 March), when the suspended sediment flux reached almost $12 \mathrm{~g} \mathrm{~m}^{-2} \mathrm{~s}^{-1}$ at both monitored depths. The timeintegrated estimated horizontal sediment transport at this site was between 0.8 and 0.9 ton $\mathrm{m}^{-2}$ and remarkably similar at 75 and 115 mab. Current speeds measured at both depth levels in SF2 were remarkably coherent (i.e. in phase) with the temporal evolution of wave height on the shelf (Fig. 8), implying a fast response to incoming storms. As in SF1, total mass and grain size of the downward flux estimated by the sediment trap at 40 mab were maximal during the main period of eastern storms (Fig. 8).

\section{Discussion}

Previous studies have highlighted the prominent role of both DSWC and shelf storms in the offshore sediment transport in the western end of the GoL, particularly when these two physical phenomena occur in synergy (or within the same season or year) and with enough intensity, resuspending and advecting sediments towards the deep following a multi-step scheme (Bonnin et al., 2008; Ulses et al., 2008a; Palanques et al., 2006, 2008). Off-shelf and along-canyon transport is known to be greater during years of intense cascading (Canals et al, 2006; Puig et al., 2008; Palanques et al., 2012). Winter 2010-2011 was relatively warm and wet with weak formation of dense water in the GoL (Rumín-Caparrós et al., 2012). In fact, horizontal and downward mass fluxes at the canyon head (Fig. 3) were relatively low when compared with previous years (Palanques et al., 2006; Ribó et al., 2011; Rumín-Caparrós et al., 2012), reflecting the lack of extreme meteorological events during this winter.

In contrast with the precedent literature on shelf-to-basin sediment transport in the GoL, which has been mainly devoted to the impact of extreme events, the present work helps to gain insight on the response of the canyon to meteorological conditions representative of an average year. In fact, a sequence of 2 moderate eastern storms (return periods between 1 and $2 \mathrm{yr}$ ) produced notable transport of sediments through the CCC, particularly along its southern flank, even though fluxes were weak at the canyon head.

\subsection{Mechanisms and sources implied in the observed particle fluxes}

Most of the sediment transport during the study took place within a short period (13-15 March) including two consecutive eastern storms. During the onset of the first of these two storms (12-13 March), the progressive downwelling associated with eastern winds was visible as warmer and less-dense water was progressively pushed down to the bottom at $300 \mathrm{~m}$ depth (Fig. 5). Subsequently, a cold and turbid water mass occupied the canyon from 150-200 to 350 m depth. Most of the sediment transport calculated during this study was as- sociated with that intrusion that was observed in the canyon, mainly along its southern canyon wall from 13 to 15 March.

In the absence of complementary data, the abrupt decrease in water temperature observed inside the canyon during that period (Figs. 4, 5, 6) could be interpreted as a tongue of cascading dense shelf water. But, contrary to our initial expectations, this water mass was actually less dense than the waters occupying the same depth stratum before the storm (Figs. 5, 6 and 9), as evidenced by simultaneous measurements of water temperature and conductivity with CTD probes, which allowed a precise determination of the density anomaly of this water body. Its position in the $T / S$ diagram (Figs. 10, 11) and namely its density $\left(\sim 28.78 \mathrm{~kg} \mathrm{~m}^{-3}\right)$ do not qualify it to cascade down-canyon driven by negative buoyancy or even to form shallow WIW (Canals et al., 2006; Puig et al., 2013). This turbid water mass observed during these dates inside the canyon at approximately 100-350 m depth was in fact lighter than the waters occupying that depth stratum before and after the main period of eastern storms and very likely was pushed into the canyon below its equilibrium depth by storminduced downwelling. In that regard, the apparent correlation (with a slight temporal decoupling $\sim 10 \mathrm{~h}$ ) of increases in significant wave height on the shelf and down-canyon current speeds (Figs. 4, 7, 8) is noteworthy. We will hereafter refer to this water mass as "coastal waters", a generic label for a water mass that we believe is strongly influenced by freshwater discharge and/or continental runoff, given its low salinity. The low temperature and low salinity of the water mass intruding the canyon during 13-15 March fits with a coastal origin, taking into account that both the temperature and salinity of the Rhône plume tend to be significantly lower than the surrounding waters, at least during winter (e.g. Omnes et al., 1996). Similar T/S hydrological signatures to the "coastal waters" described in this work (Figs. 10, 11) have been reported by Dufau-Julliand et al. (2004) over the inner GoL shelf and by Vargas-Yáñez et al. (2012) in coastal areas under the influence of the other major western Mediterranean river, the Ebro. The surface and shelf/coastal origin of this water mass was also evidenced by its high dissolved oxygen content and particle load (Fig. 6). The coastal plume extended to a depth of $\sim 350 \mathrm{~m}$, in the limit with an underlying water mass showing the hydrological signature of WIW (Fig. 11). This latter water mass could have been formed earlier that winter on the shelf, possibly in December at the time of maximum heat losses (Rumín-Caparrós et al., 2012) and when the most acute temperature drop of the winter was recorded at the canyon head (Fig. 3). Also, the prolonged period of Tramontane winds that preceded the CASCADE cruise (21 February to 3 March, Fig. 3) is a potential candidate for WIW formed offshore and then advected shoreward following the general circulation (Lacombe and Tchernia, 1972).

The eastern storms that hit the GoL from 12 March produced substantial precipitations in the Massif Central and particularly the Pyrenees watersheds. However, these 

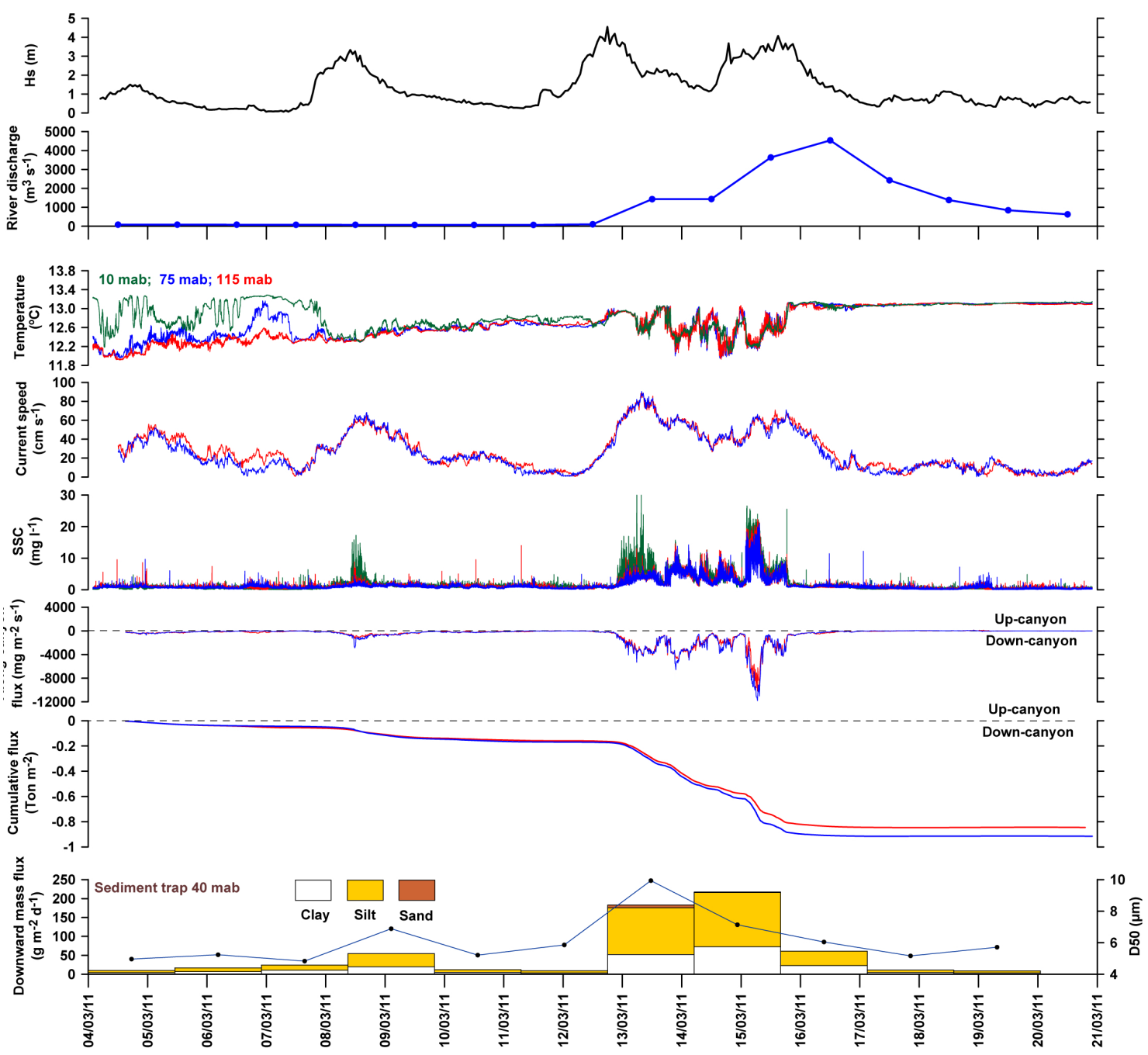

Fig. 8. Time series of water and sediment fluxes in the Cap de Creus south canyon wall (mooring SF2, see Fig. 1b for location). From top to bottom: significant wave height measured at the POEM site; total river discharge from coastal rivers opening to the Gulf of Lion (i.e. excluding the Rhône); in situ water temperature (measured by 3 Seapoint Aqualoggers), current speed measured by the ADCP at Seapoint depths, suspended sediment concentration (Seapoint), and sediment flux rotated to meet the main canyon axis (negative values are down-canyon); cumulative transport calculated from the precedent flux; downward particle flux estimated from a sediment trap at 40 mab in the same mooring line. Trap fluxes are itemized in three major grain-size classes (clay, silt, sand); the median of the grain-size distribution (d50) is also shown.

important freshwater inputs did not seem to influence the water mass detected in the canyon by 13 March and labelled as "coastal waters", since river discharge was actually low just before and during the onset of that storm and only increased notably some days after. It follows then that the SE storm of 12-13 March only flushed the freshened coastal waters present along the gulf before this stormy period. Likewise, the notable horizontal and downward mass fluxes observed from 13 to 15 March along the south CCC flank could not be fed by regional rivers, whose water discharge peaked when sediment transport sediment transport inside the canyon was already in decline (Figs. 7, 8). In fact, it has been shown in the past that most of the sediment delivered by GoL rivers remain close to the river mouth after floods and only remobilized later when energetic conditions develop again (Guillén et al., 2006). An altimeter placed at the POEM site on the adjacent inner shelf documented a sharp decrease in depth $(=4 \mathrm{~cm})$ just upon the passage of the 13 March storm (unpublished data), indicating that erosion of inner shelf sediments by storm waves, rather than river discharge, was the most likely source of sediments associated with the plume of turbid and cold water flowing along the southern canyon flank.

Water column stratification is also an important parameter to take into account to investigate the intensity of offshelf transport episodes (Palanques et al., 2008). The storm 


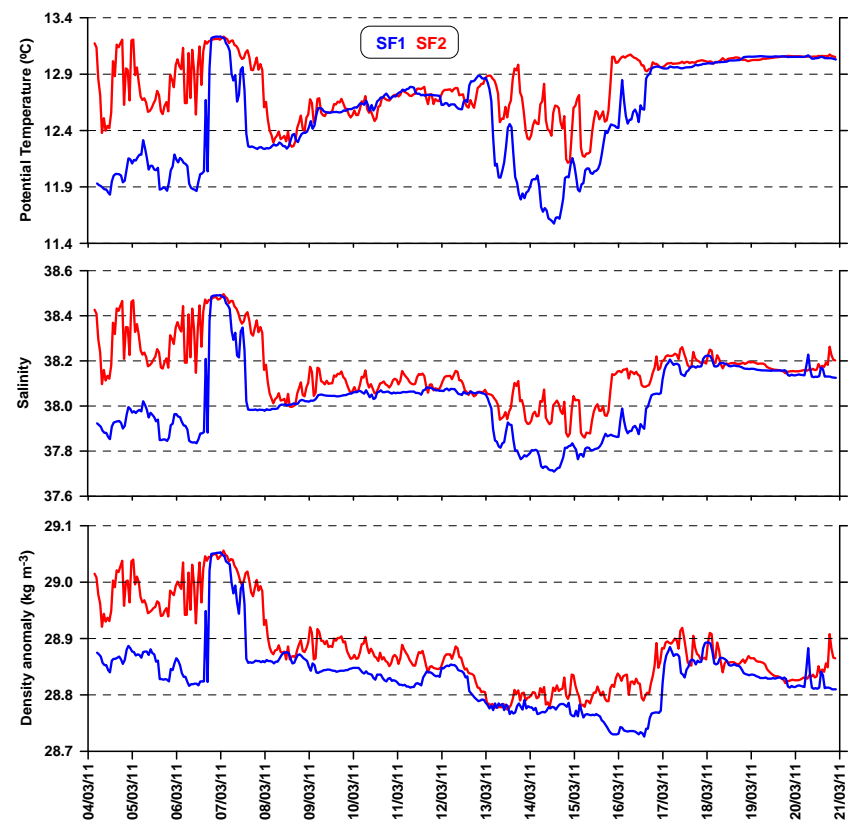

Fig. 9. Time series of potential temperature, salinity and density anomaly measured with a SBE 37-SMP probe attached 8 mab in the two mooring lines deployed on the southern CCC flank.

of 13 March did not only erode shelf sediments and induce downwelling but also mixed the upper water column (Fig. 5). As a consequence, the following storm (15 March) occurred under weaker stratification conditions, favouring the penetration to greater depths of the coastal waters. Accordingly, sediment transport at all depths and stations was maximal during the 15 March storm (Figs. 7, 8).

\subsection{Suspended sediment transport and downward particle fluxes in the CCC during March 2011}

In previous studies addressing the transport associated with storm events in the GoL, priority was given to deploying sets of instruments near the seafloor (e.g. Palanques et al., 2006, 2012), assuming that most of the sediment transport was relatively confined near the bottom. The present results seem to challenge that notion. In fact, during the main period of eastern storms and the associated downwelling, sediment transport at both mooring sites SF1 and SF2 was remarkably homogeneous in a depth range of $150-350 \mathrm{~m}$ along the southern canyon flank, as suggested by SSC at 10, 75 and 115 mab (and suspended sediment flux at 75 and $115 \mathrm{mab}$ ) within the same order of magnitude (Figs. 7, 8).

In order to estimate the total transport associated with the cold water intrusion, and since only single-point suspended sediment flux (i.e. at the depths were turbidimeters were installed) has been obtained at the mooring sites, we will rely on the CTD transect of 14 March (Fig. 6a), where more continuous and simultaneous measurements of SSC (Seapoint turbidimeter attached to the CTD probe) and current speed (ship-based ADCP) are available. Total transport has been estimated in parcels of $16 \mathrm{~m}$ height (the bin size of the ADCP) and length the average distance between consecutive CTD stations. The resulting area was multiplied by the alongcanyon suspended sediment flux. Previously, SSC data was resampled to meet the vertical resolution of current speed measurements. Assuming that the thickness, turbidity and speed of the plume of shelf waters observed on 14 March (Fig. 6a) was representative of the main downwelling period lasting about 3 days (13-15 March), a transport of $10^{5}$ metric tons of suspended sediments has been estimated as being transferred along the southern canyon flank within the turbid intrusion of coastal waters. This represents about $1 \%$ of the average annual sediment load delivered by the Rhône River (Bourrin et al., 2006). These numbers fit with the horizontal flux estimated at 75 and 115 mab at SF1 and SF2 (0.81.5 ton $\mathrm{m}^{-2}$ ), considering the thickness and lateral extension of the turbid plume. Also, it is possible that we have underestimated the total sediment transport, given that the horizontal particle flux measured at SF1 and SF2 was still relatively low during the 14 March transect and peaked markedly a day later in coincidence with the last storm of the deployment period (Figs. 7, 8).

Sediment traps recorded downward mass fluxes one order of magnitude higher in the southern canyon flank than at $\mathrm{CH}$ during the main period of eastern storms. Given the wide difference in sampling intervals between traps deployed in the south canyon flank ( $35 \mathrm{~h}$ ) and in the canyon head (15 days), a better comparison can be achieved by integrating the available data for the ensemble of the collecting period (419 March). The integrated downward mass flux thus obtained mounts up to $51.2 \mathrm{~g} \mathrm{~m}^{-2} \mathrm{~d}^{-1}$ and $55.4 \mathrm{~g} \mathrm{~m}^{-2} \mathrm{~d}^{-1}$ at $\mathrm{SF} 1$ and $\mathrm{SF} 2$, respectively, whereas it amounts to an estimated value of only $8.5 \mathrm{~g} \mathrm{~m}^{-2} \mathrm{~d}^{-1}$ in the canyon head for the same period. These numbers and comparisons must, however, be taken with caution because the high current speeds and the strong oscillations experienced by the mooring lines during the periods of maximum flux (see Fig. 2 and Sect. 2.1.3) may have affected the collection efficiency of sediment traps (Gardner, 1985).

\subsection{Transport routes during eastern storms}

Previous studies have suggested that, during major episodes of offshore transport such as cascading and storm-induced downwelling, the main water flow tends to contour the CCC following the isobaths and then enters the canyon preferentially by its southern flank, affecting only partially the canyon head. This scheme was set up by comparing simultaneous observations from $750 \mathrm{~m}$ depth in the canyon axis and the canyon head at $300 \mathrm{~m}$ (Canals et al., 2006; Puig et al., 2008; DeGeest et al., 2008), and also by means of numerical models (Ulses et al., 2008b). However this point has not yet been clearly demonstrated with direct observations on the southern canyon flank. 

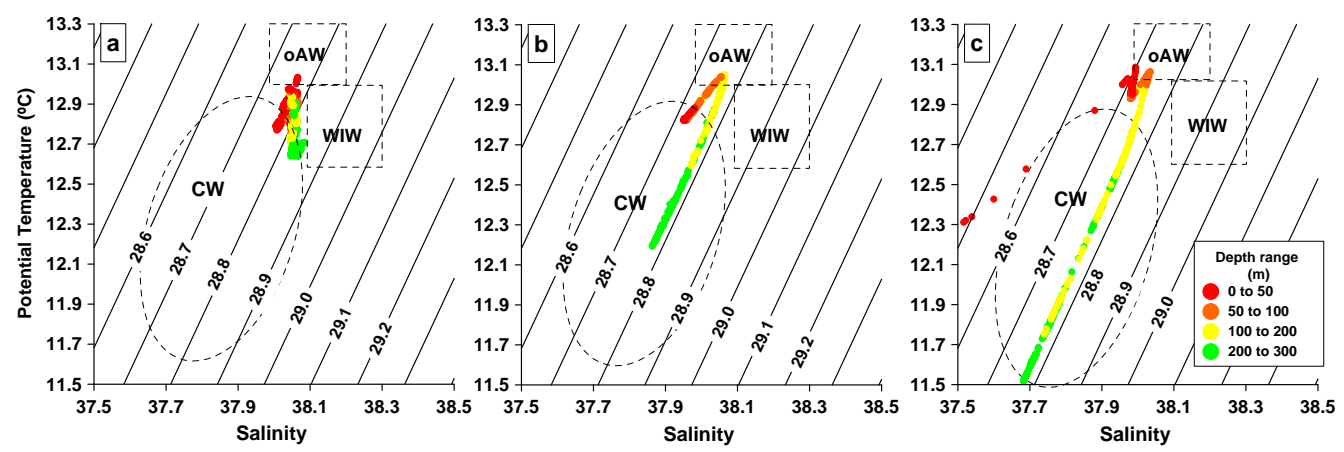

Fig. 10. $T$ / $S$ diagrams from selected CTD profiles conducted at the CX station in the Cap de Creus Canyon (a) storm setup period (ensemble of 12 CTD casts from 11 to 12/03 2011); (b, c) individual CTD casts during the peak and aftermath of the storm respectively (see the text and Fig. 5 for details). $\mathrm{CW}=$ coastal waters; WIW = Western Intermediate Waters; oAW = old Atlantic Water; LIW = Levantine Intermediate Water.
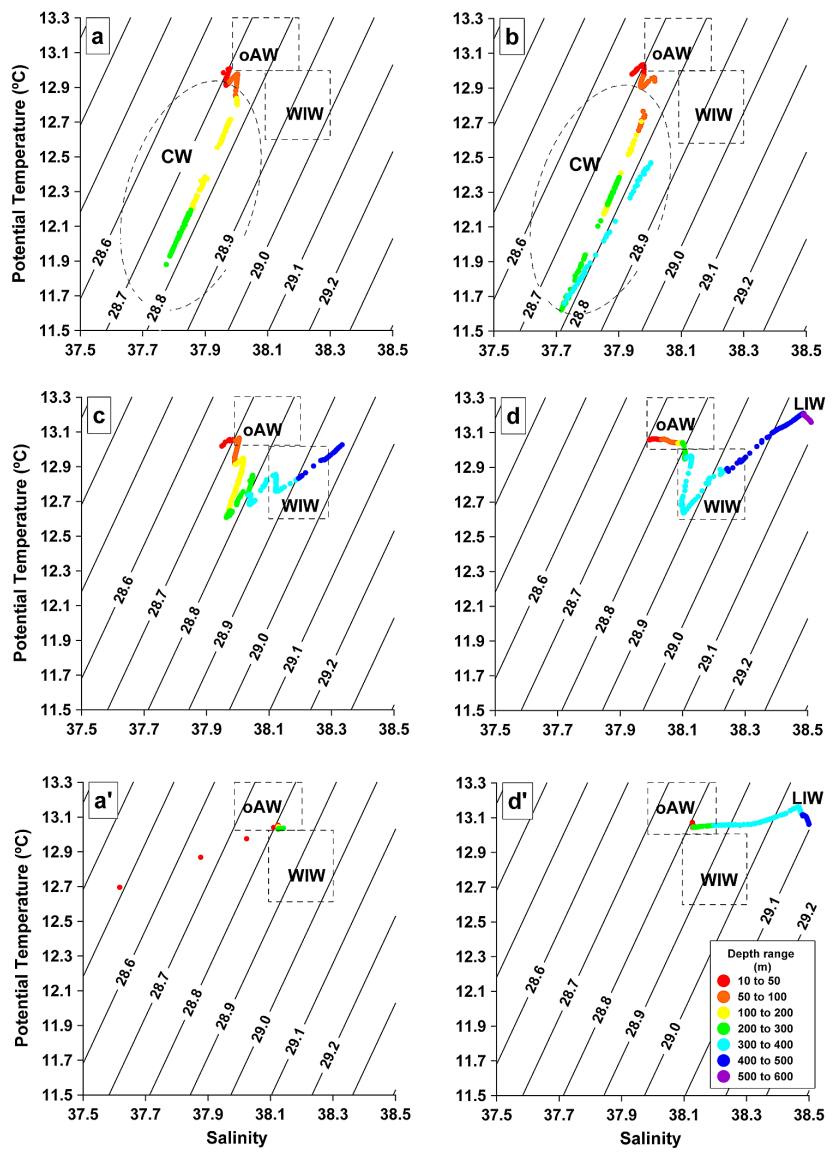

Fig. 11. $T / S$ diagrams from selected vertical profiles (see Fig. 6 for positions) conducted during two CTD transects across Cap de Creus Canyon on 14 March (a, b, c, d) and 21 March (a', d') 2011. $\mathrm{CW}=$ coastal waters; WIW $=$ Western Intermediate Waters; $\mathrm{oAW}=$ Old Atlantic Water; LIW = Levantine Intermediate Water.

At the $\mathrm{CH}$, where a long-term station allows an interannual comparison, the mild meteorological context of winter 2011 is reflected in weak sediment fluxes. In particular, during the
CASCADE cruise the downward mass flux estimated with a sediment trap at 40 mab was $<10 \mathrm{~g} \mathrm{~m}^{-2} \mathrm{~d}^{-1}$, the horizontal particle flux always below $4 \mathrm{~g} \mathrm{~m}^{-2} \mathrm{~s}^{-1}$ and the cumulative transport did not surpass 0.6 ton $\mathrm{m}^{-2}$. These values are lower than those measured in previous winters and among the lowest measured at that station since it was incepted in autumn 2004 (Canals et al., 2006, Palanques et al., 2006, 2012; Ribó et al., 2011; Rumín-Caparrós et al., 2012).

The weak horizontal and downward mass fluxes measured in the canyon head in March 2011 strongly contrast with the intense transport observed in the southern canyon flank during the same period. Sediment transport at both 75 and $115 \mathrm{mab}$ in the southern flank (both lines SF1 and SF2) was higher than near the bottom ( $5 \mathrm{mab}$ ) at the canyon head (CH). In particular, sediment transport at 75 mab in line SF1 $\left(1.5\right.$ ton $\left.\mathrm{m}^{-2}\right)$ was almost three times the one calculated at the canyon head near the bottom $\left(0.6\right.$ ton $\left.\mathrm{m}^{-2}\right)$, thus indicating preferential transport along the canyon flank.

Also, it is noteworthy that the first and weakest storm (8 March; maximum $\mathrm{Hs}=3.3 \mathrm{~m}$ ) had no noticeable influence on particle fluxes at $\mathrm{CH}$ or SF1 (Figs. 4, 7), while it clearly impacted the deepest station, SF2 (Fig. 8). This confirms the previously held idea that turbid plumes tend to contour the canyon rim, flowing close to the coastline, and enter it by its downstream side upon encountering the constrain of the Cap de Creus Peninsula. When stratification is weaker or more energetic conditions develop, the entire canyon is impacted, as evidenced for the period 13-16 March (Figs. 4-8).

\subsection{Exit routes of transient intermediate waters and implications for canyon morphology}

As the dominant eastern wind field veered to northwesterlies on 16-17 March, the flow inside the canyon reversed and the isopycnals were pushed up (Figs. 4, 6b), indicating that the plume of turbid and cold water that entered the canyon during the storm returned to its equilibrium depth at $\sim 50 \mathrm{~m}$ depth and hence left the canyon confinement. This compensation 

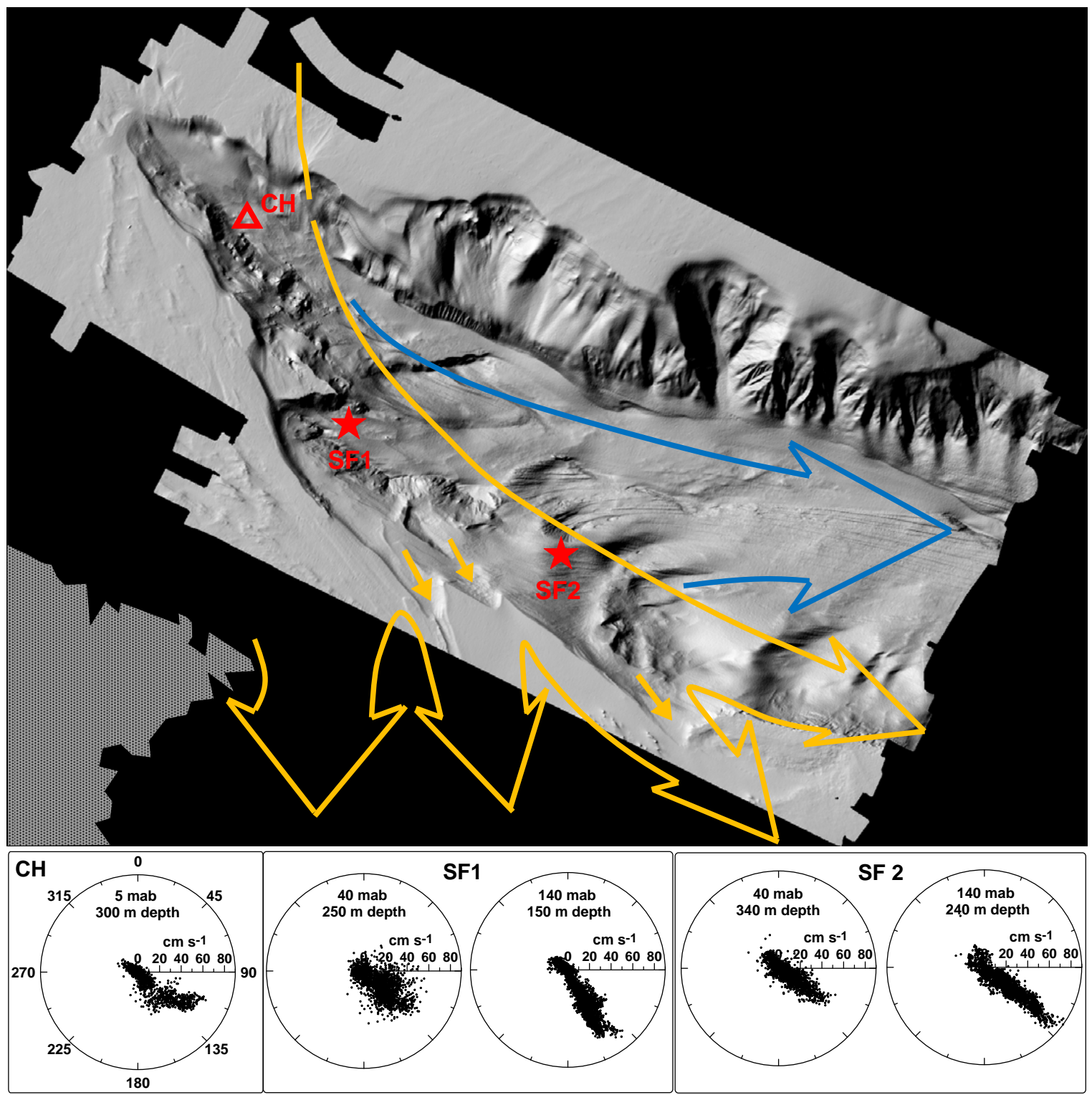

Fig. 12. Top: multibeam bathymetric map of the CCC, showing the main path of deep dense shelf water cascading (blue arrow) over a furrow field (see Puig et al., 2008), and the suggested path and exit routes for intermediate storm-downwelled shelf waters (orange arrows), hugging the southern canyon flank and causing scars on the canyon rims on the exit routes. Bottom: polar plots obtained from the canyon head station $(\mathrm{CH}, 5 \mathrm{mab})$ and the topmost $(140 \mathrm{mab})$ and bottommost $(50 \mathrm{mab})$ usable ADCP cells at the two mooring sites along the southern CCC flank are also shown.

of the isopycnals has been described as the reversal (relaxation) phase of downwelling events (Ulses et al., 2008b). Once freed from topographic control, this water mass was likely forced to flow with the mean SW circulation imposed by the Northern Current.

It has been stated that, during severe winters when shelf waters attain higher density following strong cooling and evaporation and the upper water column is more homogeneous, DSWC flows obliquely along the southern flank of the canyon, producing on its way furrow fields which ex- tends down to $1500 \mathrm{~m}$ deep (Canals et al., 2006; Lastras et al., 2007; Puig et al., 2008). On the other hand, the possible influence of storm-induced downwelling and associated current bursts around the shelf-break depth on the presentday shaping of the margin are still understudied. Figure 12 schematizes the main contemporary processes of seafloor shaping in the CCC seabed, including the formation of furrows in the deep canyon axis by the erosive action of deep DSWC (blue arrow in Fig. 12). Shallower cascading or the storm-induced downwelling process described in this work 
would rather follow the paths marked by orange arrows in Fig. 12. Polar plots of currents from the topmost and bottommost ADCP cells with valid data have also been plotted in Fig. 12. Currents closer to the seafloor were weaker and more scattered than topmost currents at the level of the canyon rim. The latter are clearly directed towards the scars visible in the canyon wall. The recurrence of E-SE storm events in the Gulf of Lion (with at least one significant storm each year) suggest, on the long-term, a causative relationship between the episodic sediment transport capacity of the strong storm-induced currents and these erosive features at the canyon rim. As documented through grain-size analysis of sediment trap samples, eastern storms can transport siltand sand-sized particles in suspension (Figs. 7, 8), which are able to abrade the canyon flank. The erosional results of the processes described here eventually overlap with those caused by shallow dense shelf water cascading following the same general direction.

\section{Conclusions}

We have documented a remarkable episode of sediment transport along the southern flank of the Cap de Creus Canyon during a series of moderate eastern storms and in the context of the mild and wet winter of 2010-2011.

Most of the along-canyon sediment transport during the monitored period (3-22 March 2011) took place during a relatively short episode (13-15 March) of dominant eastern winds comprising two consecutive storms with maximum $\mathrm{Hs}$ in the range 4.1-4.6 m. During this period, a tongue of cold, freshened and turbid water of shelf/coastal origin sank into the canyon along its southern flank to depths up to $350 \mathrm{~m}$. The intruding water was less dense than ambient waters, being pushed below its equilibrium depth by storminduced downwelling. Sediment transport along the canyon flank associated with that water body was remarkably well distributed in a range of $200 \mathrm{~m}$ above the bottom without near-bottom constriction. We provide a rough estimation of $10^{5}$ tons of suspended sediments being transported into the canyon within the downwelled coastal plume during the 3day stormy period. Regional rivers flooded after the main period of eastern storms and hence were not the main contributors to suspended sediments inside the canyon during the downwelling phase. Instead, erosion of inner shelf sediments by the action of storm waves was likely the primary source of sediments feeding the suspended particle pool of the coastal water plume intruding the canyon.

This study highlights that Cap de Creus Canyon, and particularly its southern flank, is a very significant channel for offshore sediment dispersal also in the absence of dense shelf water cascading and under mild meteorological forcing conditions.

Erosional marks in the southern canyon flank, carved in an orientation coherent with the strongest water flows measured during eastern storms, indicate that they can be at least partly caused by repeated downwelling and evacuation of intermediate water bodies during the frequent and short-lived eastern storms characteristic of the study area.

A bottom line to these observations is that, in the study area, concomitant and accurate measurements of water conductivity must complement near-bottom water temperature monitoring programmes in order to correctly interpret drops of water temperature that otherwise could be attributed solely to dense water cascading.

Acknowledgements. We are grateful to the crew and officials of $\mathrm{R} / \mathrm{V}$ l'Atalante and to all the scientific and technical staff involved in the CASCADE cruise. This work was funded by the HERMIONE Project (FP7-ENV-2008-1-226354) under the European Commission's Seventh Framework Programme, the French programme MERMEX under the MISTRALS framework, the GRACCIE-CONSOLIDER project (CSD2007-00067) and the Spanish project DOS MARES (CTM2010-21810-C03-01). University of Barcelona researchers benefitted from grant 2009 SGR 1305 by Generalitat de Catalunya to excellence research groups. L. Houpert acknowledges the support of the Direction Générale de l'Armement (supervisor: Elisabeth Gibert-Brunet). J. Martín was funded through a JAE-DOC contract within the programme "Junta para la Ampliación de Estudios", granted by Consejo Superior de Investigaciones Científicas (Spain) and co-financed by the European Social Fund. We thank the constructive comments of two reviewers who helped to improve the manuscript.

Edited by: R. Danovaro

\section{References}

Allen, S. E. and Durrieu de Madron, X.: A review of the role of submarine canyons in deep-ocean exchange with the shelf, Ocean Sci., 5, 607-620, doi:10.5194/os-5-607-2009, 2009.

Bonnin, J., Heussner, S., Calafat, A., Fabres, J., Palanques, A., Durrieu de Madron, X., Canals, M., Puig, P., Avril, J., and Delsaut, N.: Comparison of horizontal and downward particle fluxes across canyons of the Gulf of Lions (NW Mediterranean): Meteorological and hydro dynamical forcing, Cont. Shelf Res., 28, 1957-1970, 2008.

Bougis, P. and Ruivo, M.: Sur une descente des eaux superficielles en profondeur (cascading) dans le sud du Golfe du Lion, Bulletin d'Information du Comité Central d'Océanographie et d'Etude des Côtes, 6, 147-154, 1954.

Bourrin, F., Durrieu de Madron, X., and Ludwig, W.: Contribution to the study of coastal rivers and associated prodeltas to sediment supply in the Gulf of Lions, Life Environ., 56, 307-314, 2006.

Bourrin, F., Durrieu de Madron, X., Heussner, S., and Estournel, C.: Impact of winter dense water formation on shelf sediment erosion (evidence from the Gulf of Lions, NW Mediterranean), Cont. Shelf Res., 28, 1984-1999, 2008.

Buscail, R. and Germain, C.: Present-day organic matter sedimentation on the NW Mediterranean margin: Importance of off-shelf export, Limnol. Oceanogr., 42, 217-229, 1997. 
Canals, M., Puig, P., Durrieu de Madron, X., Heussner, S., Palanques, A., and Fabres, J.: Flushing submarine canyons, Nature, 444, 354-357, 2006.

DeGeest, A. L., Mullenbach, B. L., Puig, P., Nittrouer, C. A., Drexler, T. M., Durrieu de Madron, X., and Orange, D. L.: Sediment accumulation in the western Gulf of Lions, France: The role of Cap de Creus Canyon in linking shelf and slope sediment dispersal systems, Cont. Shelf Res., 28, 2031-2047, 2008.

Dewey, R. K.: Mooring Design \& Dynamics - a Matlab ${ }^{\circledR}$ package for designing and analyzing oceanographic moorings, Mar. Models, 1, 103-157, 1999.

DREAL: http://www.languedoc-roussillon. developpement-durable.gouv.fr/IMG/pdf/DREAL_LR-rapport coup_de_mer_12-16_mars_2011_cle5d39f7.pdf). 2011.

Drexler, T. M. and Nittrouer, C. A.: Stratigraphic signatures due to flood deposition near the Rhône River: Gulf of Lions, northwest Mediterranean Sea, Cont. Shelf Res., 28, 1877-1894, 2008.

Dufau-Julliand, C., Marsaleix, P., Petrenko, A., and Dekeyser, I.: Three-dimensional modeling of the Gulf of Lion's hydrodynamics (north-west Mediterranean) during January 1999 (MOOGLI3 Experiment) and late winter 1999: Western Mediterranean Intermediate Water's (WIW's) formation and its cascading over the shelf break, J. Geophys. Res., 109, C11002, doi:10.1029/2003JC002019, 2004.

Durrieu de Madron, X., Zervakis, V., Theocharis, A., and Georgopoulos, D.: Comments on "Cascades of dense water around the world ocean”, Prog. Oceanogr., 64, 83-90, 2005.

Durrieu de Madron, X., Wiberg, P. L., and Puig, P.: Sediment dynamics in the Gulf of Lions: The impact of extreme events, Cont. Shelf Res., 28, 1867-1876, 2008.

Ferré, B., Guizien, K., Durrieu de Madron, X., Palanques, A., Guillén, J., and Grémare, A.: Fine-grained sediment dynamics study during a winter storm in the Gulf of Lion shelf (NW Mediterranean), Cont. Shelf Res., 25, 2410-2427, 2005.

Firing, E. and Hummon, J. M.: Ship-mounted Acoustic Doppler Current Profilers, in: The GO-SHIP Repeat Hydrography Manual: A Collection of Expert Reports and Guidelines, edited by: Hood, E. M., Sabine, C. L., and Sloyan, B. M., IOCCP Report Number 14, ICPO Publication Series Number 134, available at: http://www.go-ship.org/HydroMan.html, 2010.

Firing, E., Ranada, J., and Caldwell, P.: Processing ADCP data with the CODAS Software System Version 3.1. User manual, Joint Institute for Marine and Atmospheric Research, University of Hawaii, USA, available at: http://epic.awi.de/29904/1/Fir1995b. pdf, 1995.

Flexas, M. M., Durrieu de Madron, X., Garcia, M. A., Canals, M., and Arnau, P.: Flow variability in the Gulf of Lions during the MATER HFF experiment (March-May 1997), J. Mar. Syst., 3334, 197-214, 2002.

Fofonoff, N. P. and Millard, R. C.: Algorithms for computation of fundamental properties of seawater, UNESCO Tech. Papers Mar. Sci., 44, 1-53, 1983.

Gardner, W. F.: The effect of tilt on sediment trap efficiency, DeepSea Res., 32, 349-361, 1985.

Guillén, J., Palanques, A., Puig, P., Durrieu de Madron X., and Nyffeler, F.: Field calibration of optical sensors for measuring suspended sediment concentration in the western Mediterranean, Sci. Mar., 64, 427-435, 2000.
Guillén, J., Bourrin, F., Palanques, A., Durrieu de Madron, X., Puig, P., and Buscail, R.: Sediment dynamics during "wet" and "dry" storm events on the Têt inner shelf (SW Gulf of Lions), Mar. Geol., 234, 129-142, 2006.

Guizien, K.: Spatial variability of wave conditions in the Gulf of Lions (NW Mediterranean Sea), Vie Milieu, 59, 261-270, 2009.

Harris, P. T. and Whiteway, T.: Global distribution of large submarine canyons: Geomorphic differences between active and passive continental margins, Mar. Geol., 285, 69-86, 2011.

Heussner, S., Ratti, C., and Carbonne, J.: The PPS 3 time-series sediment trap and the trap sample processing techniques used during the ECOMARGE experiment, Cont. Shelf. Res., 10, $943-$ 958, 1990.

Heussner, S., Calafat, A., and Palanques, A.: Quantitative and qualitative features of particle fluxes in the North Balearic basin, in: Euromarge-NB final report, MAST II program, EU, Vol. IIIB, edited by: Canals, M., Casamor, J. L., Cacho, I., Calafat, A. M., Monaco, A., RGMG-University of Barcelona, Barcelona, 43-66, 1996.

Heussner, S., Durrieu de Madron, X., Calafat, A., Canals, M., Carbonne, J., Delsaut, N., and Saragoni, G.: Spatial and temporal variability of downward particle fluxes on a continental slope: Lessons from an 8-yr experiment in the Gulf of Lions (NW Mediterranean), Mar. Geol., 234, 63-92, 2006.

Hickey, B. M.: The response of a steep-sided, narrow canyon to time-variable wind forcing, J. Phys. Oceanogr., 27, 697-728, 1997.

Huthnance, J. M.: Circulation, exchange and water masses at the ocean margin: the role of physical processes at the shelf edge, Prog. Oceanogr., 35, 353-431, 1995.

Jahnke, R. A., Reimers, C. E., and Craven, D. B.: Intensification of recycling of organic matter at the sea floor near ocean margins, Nature, 348, 50-54, 1990.

Lacombe, H. and Tchernia, P.: Le problème de la formation des eaux marines profondes, Déroulement du phénomène en Méditerranée Nord-Occidentale par hiver très froid (JanvierMars 1963), Ann. Inst. Océanogr., 48, 1-112, 1972.

Lapouyade, A. and Durrieu de Madron, X.: Seasonal variability of the advective transport of particulate matter and organic carbon in the Gulf of Lion (NW Mediterranean), Oceanol. Acta, 24, 295-312, 2001.

Lastras, G., Canals, M., Urgeles, R., Amblàs, D., Ivanov, M., Droz, L., Dennielou, B., Fabrés, J., Schoolmeester, T., Akhmetzhanov, A., Orange, D., and García-García, A.: A walk down the Cap de Creus canyon, northwestern Mediterranean Sea: Recent processes inferred from morphology and sediment bedforms, Mar. Geol., 246, 176-192, 2007.

Martín, J., Palanques, A., and Puig, P.: Near-bottom horizontal transfer of particulate matter in the Palamós submarine canyon (NW Mediterranean), J. Mar. Res., 65, 193-218, 2007.

Martín, J., Palanques, A., Vitorino, J., Oliveira, A., and de Stigter, H.: Near-bottom downward flux of particulate matter in the Nazaré submarine canyon during normal and stormy conditions, Deep-Sea Res. Pt. II, 58, 2388-2400, 2011.

Millot, C.: The Gulf of Lions' hydrodynamic, Cont. Shelf Res., 10, 885-894, 1990.

Millot, C.: Circulation in the Western Mediterranean Sea, J. Mar. Sys., 20, 423-442, 1999. 
Monaco, A., Courp, T., Heussner, S., Carbonne, J., Fowler, S. W., and Deniaux, B.: Seasonality and composition of particulate fluxes during ECOMARGE-I western Gulf of Lions, Cont. Shelf Res., 9-11, 959-987, 1990.

Omnes, P., Slavyk, G., Garcia, N., and Bonin, P.: Evidence of denitrification and nitrate ammonification in the River Rhône plume (northwestern Mediterranean Sea), Mar. Ecol.-Prog. Ser., 141, 275-281, 1996.

Palanques, A., Durrieu de Madron, X., Puig, P., Fabrés, J., Guillén, J., Calafat, A., Canals, M., Heussner, S., and Bonnin, J.: Suspended sediment fluxes and transport processes in the Gulf of Lions submarine canyons. The role of storms and dense water cascading, Mar. Geol., 234, 43-61, 2006.

Palanques, A., Guillén, J., Puig, P., and Durrieu de Madron, X.: Storm-driven shelf-to-canyon suspended sediment transport at the southwestern end of the Gulf of Lions, Cont. Shelf Res., 28, 1947-1956, 2008.

Palanques, A., Puig, P., Guillén, J., Durrieu de Madron, X., Latasa, M., Scharek, R., and Martín, J.: Effects of storm events on the shelf-to-basin sediment transport in the southwestern end of the Gulf of Lions (Northwestern Mediterranean), Nat. Hazards Earth Syst. Sci., 11, 843-850, doi:10.5194/nhess-11-843-2011, 2011.

Palanques, A., Puig, P., Durrieu de Madron, X., Sánchez-Vidal, A., Pascual, C., Martín, J., Calafat, A., Heussner, S., and Canals, M.: Sediment transport to the deep canyons and open-slope of the western Gulf of Lions during the 2006 intense cascading and open-sea convection period, Prog. Oceanogr., 106, 1-15, 2012.

Pasqual, C., Sanchez-Vidal, A., Zúñiga, D., Calafat, A., Canals, M., Durrieu de Madron, X., Puig, P., Heussner, S., Palanques, A., and Delsaut, N.: Flux and composition of settling particles across the continental margin of the Gulf of Lion: the role of dense shelf water cascading, Biogeosciences, 7, 217-231, doi:10.5194/bg-7217-2010, 2010.

Pfannkuche, O.: Benthic response to the sedimentation of particulate organic matter at the BIOTRANS station, $47^{\circ} \mathrm{N}, 20^{\circ} \mathrm{W}$, Deep-Sea Res. Pt. II, 40, 135-149, 1993.

Puig, P., Palanques, A., Sanchez-Cabeza, J. A., and Masqué, P.: Heavy metals in particulate matter and sediments in the southern Barcelona sedimentation system (North-western Mediterranean), Mar. Chem., 63, 311-329, 1999.
Puig, P., Palanques, A., Guillén, J., and El Khatab, M.: Role of internal waves in the generation of nepheloid layers on the northwestern Alboran slope: Implications for continental margin shaping, J. Geophys. Res., 109, C09011, doi:10.1029/2004JC002394, 2004.

Puig, P., Palanques, A., Orange, D. L., Lastras, G., and Canals, M.: Dense shelf water cascades and sedimentary furrow formation in the Cap de Creus Canyon, northwestern Mediterranean Sea, Cont. Shelf Res., 28, 2017-2030, 2008.

Puig, P., Durrieu de Madron, X., Salat, J., Schroeder, K., Martín, J., Karageorgis, A., Palanques, A., Roullier, F., López-Jurado, J. L., Emelianov, M., Moutin, T., and Houpert, L.: Thick bottom nepheloid layers in the western Mediterranean generated by deep dense shelf water cascading events, Prog. Oceanogr., 111, 1-23, 2013.

Ribó, M., Puig, P., Palanques, A., and Lo Iacono, C.: Dense shelf water cascades in the Cap de Creus and Palamós submarine canyons during winters 2007 and 2008, Mar. Geol., 284, 175188, 2011.

Rumín-Caparrós, A., Sanchez-Vidal, A., Calafat, A., Canals, M., Martín, J., Puig, P., and Pedrosa-Pàmies, R.: External forcings, oceanographic processes and particle flux dynamics in Cap de Creus submarine canyon, NW Mediterranean Sea, Biogeosciences Discuss., 9, 18571-18600, doi:10.5194/bgd-9-185712012, 2012.

Ulses, C., Estournel, C., Durrieu de Madron, X., and Palanques, A.: Suspended sediment transport in the Gulf of Lions (NW Mediterranean): impact of extreme storms and floods, Cont. Shelf Res., 28, 2048-2070, 2008a.

Ulses, C., Estournel, C., Bonnin, J., Durrieu de Madron, X., and Marsaleix, P.: Impact of storms and dense water cascading on shelf-slope exchanges in the Gulf of Lion (NW Mediterranean), J. Geophys. Res., 113, C02010, doi:10.1029/2006JC003795, 2008b.

Vargas-Yáñez, M., Zunino, P., Schroeder, K., López-Jurado, J. L., Plaza, F., Serra, M., Castro, C., García-Martínez, M. C., Moya, F., and Salat, J.: Extreme Western Intermediate Water formation in winter 2010, J. Mar. Syst., 105-108, 52-59, 2012. 